I NTER NATIONAL MONETARY FUND

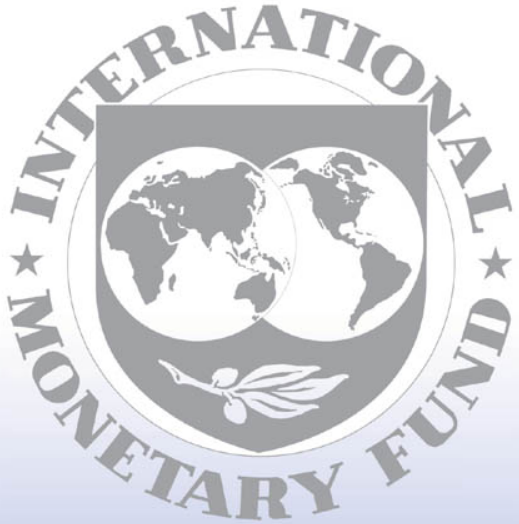

Staff

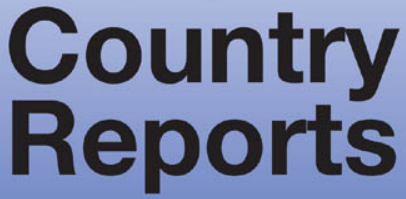




\section{Cape Verde: Poverty Reduction Strategy Paper-Progress Report}

Poverty Reduction Strategy Papers (PRSPs) are prepared by member countries in broad consultation with stakeholders and development partners, including the staffs of the World Bank and the IMF. Updated every three years with annual progress reports, they describe the country's macroeconomic, structural, and social policies in support of growth and poverty reduction, as well as associated external financing needs and major sources of financing. This country document for Cape Verde is being made available on the IMF website, together with the Annual Progress Report, by agreement with the member country as a service to users of the IMF website.

Copies of this report are available to the public from

International Monetary Fund • Publication Services

$70019^{\text {th }}$ Street, N.W. • Washington, D.C. 20431

Telephone: (202) 623-7430 • Telefax: (202) 623-7201

E-mail: publications@imf.org Internet: http://www.imf.org

\section{International Monetary Fund Washington, D.C.}


Ministry of Finance

National Planning Department

\section{Cape Verde}

Global Report on the Progress of Execution of the Growth and Poverty Reduction Strategy (GPRSP II)

2009

Praia, April 2010

(C)International Monetary Fund. Not for Redistribution 


\section{0 . Introduction}

This report has been produced in accordance with commitments made under the terms of the budgetary assistance provided to Cape Verde and the memoranda of understanding that have been signed.

The country's development policy has evolved in a setting of severe structural constraints and persistent restrictions, ${ }^{1}$ with potential impediments to growth that include energy, transport, and geographic factors. Despite these structural challenges, Cape Verde is pressing ahead with a bold vision of development founded on a strong and dynamic productive system. ${ }^{2}$ Turning the vision into reality, however, requires human resource development based on technology and culture, embedded in a context of balanced regional development, solidarity, social justice, democracy, and environmental awareness. That this vision is feasible is evidenced by significant achievements such as democratic stability, good governance, a high human development index, improved labor relations, social protection and poverty reduction, and a rapid increase in per capita income.

Good governance and the growing credibility of the State and its institutions have proven to be strategic resources for development and are decisive for forming partnerships and alliances to mobilize resources for development programs, and to guarantee peace, stability and the solidity of the institutions of democracy and the rule of law.

In view of the development results it has achieved, Cape Verde has entered a new phase of development (transition from least developed country status, accession to the World Trade Organization (WTO) and the signing a special partnership agreement with the European Union), in which it will face new challenges. One of the prices to be paid for this success is no longer being eligible for concessional foreign aid.

Cape Verde's major ambition is to become a prosperous nation based on a modern a competitive economy. The ongoing process of change adopts a Transformation Strategy closely linked to the consolidation of democracy based on sound institutions. Democratic strengthening is essential and presupposes the consolidation of good governance as a key factor in any development strategy.

The growth and poverty reduction strategy paper (GPRSP) is a planning tool that articulates the various sector development policies and strategies. This second progress report on execution of the second strategy document (GPRSP II 2008-2011) focuses on achievements in 2009 .

\footnotetext{
${ }^{1}$ Cape Verde: Constraints to Growth, Transformation and Poverty Alleviation

${ }^{2}$ Ambitious vision of the country's future.
} 
The information contained in this report was obtained mainly from the individual sectors and their evaluations - sector-level studies undertaken in conjunction with the sectors themselves, to monitor implementation of the actions specified in the budget support framework.

\section{Revisiting the vision and strategic pillars}

For 2008-2011, the GPRSP expects the country to achieve "sustainable human development based on a strong, dynamic productive system, on the enhancement of its human capital, technological training, and its culture, in the context of balanced regional development, solidarity, social justice, democracy, and environmental awareness.” The strategy's global view is based on the medium-term strategic objectives summarized below:

- Transformation of the government as a whole, based on the reform of public administration and strengthening of municipal governments;

- Improvement of the quality of life of Cape Verdean citizens, with the creation of more participation spaces, and affirmation of nation status and gains for democracy;

- A modern, competitive economy, with a view to reducing unemployment below 10 percent and achieving double-digit GDP growth rates;

- The knowledge society for innovation, skills, and employment, and new information technologies to upgrade human resources;

- Strengthening of capacities to manage national development, involving institutional capacity building for monitoring and evaluation; and

- Social solidarity with a view to poverty reduction.

These strategic objectives will be achieved by implementing the following five strategic pillars: (i) Good governance/government reform, the key element of which involves ensuring that the government's regulatory function is exercised transparently in public administration; (ii) Human capital, where capacity-building in terms of resources and institutions involves modernizing the education and technical-vocational training system, structuring and improvement of the quality of health services, promotion of culture, and youth and sports programs; (iii) Competitiveness, which should be underpinned by the macroeconomic stability needed for the country's development; (iv) Economic and social infrastructure promoting regional development and territorial cohesion. (v) Social cohesion, which includes improvements in work conditions and working relations, the social protection system, making employment more dynamic, and food security.

\section{Macroeconomic framework}

\section{Strategic orientations:}

- Strong and sustained growth founded on macroeconomic stability, which will create wealth and employment, and lead to poverty reduction and social inclusion. 
- A competitive economy based on skilled human resources, productivity, quality, and innovation.

The most recent estimates of economic trends made by the Ministry of Finance for 2009 suggest:

- GDP growth rate around 4.5 percent, slightly below the 2000-2006 average of 5.4 percent (INE, 2006). Projections suggest somewhat tentative recoveries in 2010 and 2011, at rates well below those anticipated in the GPRSP II (8.4 percent and 10.2 percent, respectively).

Although slightly below the 5 percent projected by the 2010 State budget, the estimates reflect the economy's resilience in 2009, a year of global economic recession with average GDP growth of -0.8 percent. The negative repercussions of that recession were mitigated by large-scale government support to the economy, facilitated by the fiscal/budgetary cushion that had been built up in earlier years. Particularly noteworthy was the trend of domestic demand, strengthened by the supportive budgetary measures adopted to alleviate the negative repercussions of the crisis and protect families' purchasing power and business competitiveness; and the reprogramming of the 2009 State budget at the start of the year, which introduced an economic stimulus package with an integrating approach to social cohesion. Other aspects of the macroeconomic scenario include the following:

- The country's chronic trade deficit declined sharply in the fourth quarter of 2009 (26.7 percent in the same period of the previous year), as a result of a 9.8 percent overall reduction in merchandise imports and an 18 percent expansion of exports, accompanied by a slowdown in national economic activity.

- The inflation rate in 2009 was forecast at 1.4 percent, a decrease stemming from the easing of the inflationary pressures exerted by world food and oil prices. The target set in the matrix for 2009 was well below 2.8 percent.

- Foreign direct investment (FDI) outstripped public development aid (PDA). Migrant remittances remained important although their impact has declined owing to the growth in tourism earnings. Remittances declined slightly by 0.6 percent. In contrast, FDI contracted sharply, by about 40.4 percent, compared to the previous year's level, reversing the positive trend of the last few years.

- Public investment in 2009, in line with the agreed target, should attain the 2007 baseline of 13.9 percent.

- Foreign exchange reserves, measured in import months (3.3 months for 2009), shrank by 1.6 percent as a result of smaller external capital inflows. 
- Unemployment trends have been encouraging over the last few years. Adult unemployment dropped to 18 percent in 2008, and a target of 15 percent was set for 2009. Steps are being taken to help women heads of family, the group worst affected by unemployment, to find jobs, to overcome this constraint.

- Per capita income reached a level of US\$2316.

- The health budget was 98 percent executed (SIGOF budget software), compared to the target of 80 percent set in the GPRSP II framework.

- The education budget was 82 percent executed, compared to the 80 percent set in the GPRSP II framework.

- The demographic growth rate forecast for 2007 (2007 Household Survey - QUIBB) was below 2 percent per year. Women account for 51.6 percent of the total population and 46 percent of the economically active population, and head 46 percent of Cape Verdean families.

- Male and female life expectancy at birth is 72.3 and 76.1 years respectively.

- The country's human development index (HDI) is 0.736 , compared to the 0.722 defined as a baseline for 2007 .

- The infant mortality rate has declined over the years, and in 2009 stood at 21.7 per 1,000 live births. Child mortality in the first six years of life has remained stable over the last three years.

\subsection{Public Finance}

Following the recovery of credibility and capacity to mobilize funds from development partners, which led to the signing of several loan agreements and grants totaling around US\$600 million, budgetary execution has been deconcentrated for sectors/ministries, particularly in terms of the appropriation and payment in the SIGOF. This situation allows for automatic accounting and storing of execution data in the single SIGOF database, which improves data reliability and shortens the time needed to prepare the general government account.

- The budget execution manual was produced.

- Provisional execution of public accounts for 2009 shows an overall budget balance of - 5.7 percent of GDP, almost 4.8 percentage points of GDP above the previous year's figure. 
The current balance displays a surplus of 2,739 million Cape Verdean escudos (CVE), about 61.8 percent lower than in the same period last year, reflecting the less favorable trend in current revenues in relation to current expenditure. The primary balance was -9.1 percent of GDP, which represents a deterioration compared to the same period last year ( -5 percent of GDP).

Total income (including food aid and grants) amounted to 25.7 percent of GDP, down by 4.2 percentage points on the previous year's figure, or an 8.9 percent reduction in relative terms. This trend basically reflects the behavior of tax revenues which showed clear signs of faltering, and the failure to collect income from land sales. The contraction in tax revenue, of about 13.2 percent, is explained by the trend of direct and indirect taxes which declined by 5.5 percent and 16.3 percent, respectively, compared to the same period in the previous year, partly as a result of steps taken to reduce the tax burden in 2009 and the impact of the international crisis on certain sectors of economic activity.

Public expenditure grew by around 8 percent year-on-year, which mainly reflects an increase in investment expenditure of about 9.6 percent, together with current expenditure growth of around 7 percent, partly owing to larger current transfers ( 8.9 percent) and payroll expenses ( 8 percent) together with a reduction in subsidies and other expenses of 9.4 percent and 0.7 percent, respectively. On the Investment expenditure front, the execution rate was around 85 percent. These developments contributed to public expenditure growth of around 31.4 percent of GDP in 2009, up by 0.6 percentage points of GDP compared to the previous year.

- In 2009, public debt was equivalent to 59.4 percent of GDP, well below the ceiling (70 percent) set under the Policy Support Instrument (PSI) agreed upon with the IMF, and about 1.9 percent above its GDP share in 2008.

In relative terms, total public debt grew by about 9.5 percent. In component terms, external debt grew to 40.3 percent of GDP, while domestic debt amounted to 19.1 percent of GDP, thus in line with the target agreed upon in the aforementioned PSI.

- In the monetary sector, domestic credit trended upwards by about 10.5 percent compared to the same period in the comparison year (2008), based mainly on an expansion of credit to the economy of around 11.8 percent, which, in turn, fuelled a rising trend in lending to the private sector, given that nearly all credit in the economy goes to that sector.

Lending to the public sector also grew by about 5.5 percent in, in the wake of an expansion of lending to central government ( 7.5 percent), thus reversing the downward trend of this item in previous years. This is explained by the increase in the government's financing needs following its efforts to execute an economic stimulus policy.

- The money supply grew by 3.3 percent year-on-year, amounting to a total of CVE 105,451.7 million in December. 
- The performance of the external accounts reflects the impact of the unfavorable international climate in 2009. Exports of goods and services shrank by around 11.9 percent, which in the services sector was largely due to a significant drop in tourism income of around 17.6 percent. Imports of goods and services also declined by around 9 percent.

3. The strategic pillars

\subsubsection{Pillar I - Good governance/Government reform}

Good governance has been a crucial factor for consolidating the country's success, and creating conditions to make this irreversible, and for the growing credibility of the State and its institutions. Good governance is a strategic resource for the country's development, particularly in terms of transparent governance and respect for the law.

\subsubsection{Reform of government and public administration}

Strategic orientations:

- Government reform

- Gradual upgrading of the government apparatus in its eminently regulatory function.

- Modernization of administrative machinery, to improve the efficiency and effectiveness of policies and policy measures.

- Implementation of the Strategic Program for the Information Society and the Plan of Action for Electronic Government.

- Rationalization and reduction of public expenditure.

- Public administration

- Adoption of major instruments to steer public policies in the reform of public administration.

- Upgrading of public services and motivation of human resources.

- The rationalization of structures with a view to modernizing public administration has the appropriate inputs in the new Basic Law on Structures, the establishment of the 
Strategic Policies Center, and improvement of human resource training and skill development.

- The report on the financial and institutional impact (between 2006 and 2010) and on the new prospects for rationalization of public administration is currently being prepared.

- Public administration human resource management tools (the Basic Public Finance Law, PCCS, performance appraisal, review of the management and special executive staff statute in 2009) were reviewed and completed.

- Ongoing professional development of public administration human resources has been concluded and the Council of Ministers has approved the RE training plan. The public-sector managers training course was also completed. Forward-looking human resource management and deconcentration of the human resources database at the ministerial level, were made possible by the progress made in 2003, 2004, and 2005.

As regards administration/governance that is closer to citizens, e-government is fundamental in reducing costs and attracting FDI and for improving the competitiveness of established firms.

The main achievements include:

- Launch of the multiuse service; approval by the Council of Ministers of the strategic plan for expanding the Citizens Center (Casa do Cidadão) and ISO 9001 certification of thereof.

- The reform and regulation of public procurement was completed, along with human resource training in 2009.

- The reform agenda was publicized on several of the country's islands in 2009, targeting media partners, economic agents, public-sector managers, and the development of Internet sites.

Meanwhile, the introduction of the biometric passport (PEC), an important component of egovernment and administrative modernization, is at an advanced stage, but had not been completed in 2009.

The PEC will form part of the National Identification and Civil Authentication System (SNIAC) which will use a single database and an integrated technological structure to issue identification and travel documents (national identity card, residence card and electronic passport). 
As a result of its sound governance over the last few years, Cape Verde today displays good indices of external credibility; and externally it is projecting a reliable, safe, and competitive country image. This result is widely recognized by the national community and our development partners.

Consequently, modern public administration management criteria are being applied, and indicators such as publications on the rights of civil servants and performance appraisal tools have been produced. Cape Verde offers economic freedoms in terms of business, bureaucratic expenses, and monetary freedom that compare favorably with those of other countries around the world.

Nonetheless, despite the gains in implementing reforms, public administration needs to overcome constraints that still hinder its rapid modernization and make it difficult to achieve higher levels of efficiency.

\subsubsection{Decentralization, local government}

\section{Strategic orientations:}

- Consolidation and deepening of local power and capacity building among its human resources

- Consolidation of municipal autonomy

- Modernization of municipal administration

- Promotion of municipal solidarity and consolidation of the rule of law.

The medium-term objective set in the GPRSP II is to implement the decentralization policy.

Activities implemented in 2009 include:

- Creation of a network of partners (ANMCV, Uni_CV, IEFP, UCRE) to design and implement a technical training plan for municipalities in the areas of administrative, financial, capital, and human resource planning and management.

- Provision of technical assistance to the municipalities and an improvement in partnership relations between the Directorate-General of Local Administration (DGAL) and the municipalities; further training for municipalities in terms of financial management and municipal law.

- Dissemination of the proposed review of municipal statutes in Praia, Fogo, São Nicolau, Santo Antão, and São Vicente. 
The new version is currently in Parliament for final approval. The statutes aim to strengthen municipal competencies, capacity for inspection and control of municipal teams by municipal deliberative bodies, and participation by municipalities in the decisions and organization of administrative and urban planning and management services, which are sensitive areas of municipal management.

- A version of the study on the decentralization and strengthening of governance was produced and published in Praia.

The study provides inputs for adopting new policy measures for municipal modernization and development, strengthening of good governance, and social cohesion.

- The Framework Law on the Administrative Decentralization of the country was also approved.

The law defines clear legal and methodological guidelines for the decentralization process, the sharing of jurisdictions and competencies between central and local administration, and the transfer of the necessary resources.

- A law was passed defining the administrative categories of small population centers (povoações) and procedures for promotion to towns (vilas) and cities (cidades), as well as the criteria and responsibilities of municipalities and the government.

- An international forum on local governance and territorial development was held in the city of Praia, for public and private entities, with participation by international presenters.

- The Municipal Information System (SIM) was set up and installed in 17 municipalities.

The SIM substantially improved communications between the municipalities and central government. It also brought about a considerable improvement in municipal fiscal and financial management - reflected in gains in efficiency and management rigor; greater transparency and speed in terms of accountability; and more efficient provision of services to users.

- In terms of borrowing, the law governing lending to municipalities is regulated with a view to adaptation to the economic and technical borrowing capacity of the municipalities. The latest update mentions the existence of a final regulation proposal (December 2009). 
Development of the "participatory budget" project is in the phase of recruiting technical assistance, training/awareness-raising among municipal authorities and civil society in pilot municipalities, and the design of a dedicated website (www.op-caboverde.org), with work set to continue in 2010 .

\subsubsection{Justice and security in national territory}

Strategic orientations: 1 . Justice

- Reform of judiciary organization.

- Implementation of the reform of Judicial Secretariats and the Attorney General's Office.

- Continued upgrading of existing judicial resources.

- Adoption of a consistent policy for continuous upgrading and training of justice workers in the process and new technology areas.

- Development and finalization of court computerization.

- Strengthening of the fight against gender violence with a view to speeding up the legal response and providing a breakdown of statistical data on crimes involving gender-based violence.

- Promotion of access to the law, in its fundamental aspect of legal information.

2. Security

- Improvement of the training and specialization of the various police forces in the National Police.

- Development of a system for coordinating those police forces with a view to dismantling organized criminal networks and strengthening national security.

In terms of institutional development and improvement of legislation, achievements in 2009 include:

- Institutional reorganization of the National Police (PN).

- Internal dissemination of projects on the staff charter, disciplinary regulation, remuneration charter, and regulation of national police identification criteria. 
- The following legal instruments were approved: (i) the Law Defining the Legal Regime Governing Private Security Activity in Cape Verde (Law No. 50/VII/2009); (ii) the New Organic Law of MAI, which has not yet been published; (iii) the Law on Alcohol, approved by Parliament in general terms; (iv) the Decree Law providing for the Special Regularization of Immigrants (not published); and (v) the legal instrument for special regularization of Guinean migrants (not published).

Security in national territory. Security was incorporated in December 2009 during the preparatory work in relation to the Special Partnership with the European Union and in the context of international determination to mitigate the consequences of organized cross-border crime and trafficking in narcotics, hallucinatory drugs, and people.

Significant progress and concrete results have been achieved in terms of improving the quality of security in 2009.

- A joint sector monitoring framework was prepared for the sector, and its implementation will be coordinated between ministries. This matrix nonetheless needs a number of clarifications, as recognized by the partners in the sectors involved.

The indicator of institutional strengthening and coordination is being materialized by implementing legal measures and joint exercises and operations with the judicial police and national police force.

- Training and inspection actions, in partnership with countries such as Portugal, Spain, France, the United Kingdom, and the United States, have continued pursuant to the program and agreements signed with those countries. Joint exercises were held, involving patrol, vessel boarding, identification of vessels and other activities for a total of 202 days, equivalent to 7,152 hours.

- The strategic plan for domestic security was approved, which includes three priority programs targeting violence, criminality, maintenance of security, tranquility and public order, and territorial security.

- The basic instruments of the PSS were prepared: the framework collective security program, a general framework that establishes criteria for presenting projects for financing and the local security contract model.

In terms of prevention and combating crime: 
- The proportion of cases $^{3}$ investigated by the judicial police and sent to the Attorney General's Office for the purpose of formal prosecution was 66 percent in 2009, compared to a target of 55 percent.

- 26 specialized training events were held for 158 staff, which exceeds the target set.

- The first tranche of the disbursement for purchasing equipment to set up joint teams in airports and ports was released in 2009. The Praia team operates with personnel from the PJ, with elements from the National Police still to be incorporated.

In terms of protecting citizens rights:

- Protection mechanisms were set up and strengthened with the operation of legal advice bureaus (Casas de Direito) (11 CDs projected to operate in 2009, X operating).

- The report on the fight against corruption and criminality was produced and presented together with an improvement plan for 2010.

- The project creating and making operational the Brigade for Investigation and Combating Criminality (BIC2) was completed. The official document was not published.

- Operational staff received training to gradually join this new unit over the next three years.

In relation to the security sector, there is a consensus on the need for a dialogue, consensus and operational coordination mechanism.

- The Operational Security Coordination Team (ECOS), created by CM Resolution No. 6/2005 of February 28, continues to function.

Making the territory secure involves reform and modernization of the country's borders. In this regard, and as anticipated, in 2009:

- The automatic exit and entries security process (the PASSE system) was installed and put into operation in the airports of Praia and Sal, combining the requirements of good security control with the need to facilitate circulation.

3 Calculated by dividing the total number of cases resulting in a formal charge by the total number of processes sent to the Attorney General's Office. 


\subsubsection{Prison and Social Reintegration Services}

The reform and modernization of the prison service proposed for 2009 under the special $\mathrm{CV} / \mathrm{EU}$ partnership has produced following results in relation to the four indicators adopted:

- Number of prison inmates receiving vocational training: 248 in the prisons of Praia, São Vicente, Fogo, and Santa Catarina. Training actions included carpentry and masonry, hairdressing; prevention of drug abuse and HIV/AIDS; electricity; introduction to information technology; leather arts; and garment making level 1.

- Number of prison inmates receiving literacy training: first, second, and third phase adult literacy training actions were implemented in partnership with the DGAEA, for 158 inmates in the central prisons of Praia and São Vicente, and the regional prisons of Fogo and Santa Catarina.

- Of the two prison establishments still to be built, equipped and implemented, a new prison complex was built and equipped in the central prison of São Martinho in Praia.

- Number of agents participating in specialized training for prison guards in the central and regional prisons.

In terms of training/skill development in 2009, the PN implemented about 40 actions in a very wide variety of specialization areas, such as air and maritime borders, prevention of clandestine immigration, piloting and maintenance of vessels, criminal investigation, courses for promotion to unit chiefs, work practice for officers with directorship and department chief functions, criminal fires, initial pedagogic training for trainers, police intervention techniques, among others, covering about 478 personnel.

The fight against drugs has emphasized a balanced and integrated approach covering aspects of prevention, treatment, and social reintegration, and suppression. In the framework of preventing and combating drugs and criminality:

- 238 new agents were trained and incorporated, compared to the 210 previously envisaged. At this time, another 60 agents are currently in training. Over 400 agents trained and incorporated into the national police force in the last three years.

- A process was initiated to create a database of information from the SOS drugs line, support for groups, grassroots community organizations, NGOs, and individuals working in prevention, treatment, and apprehension of drug addicts.

The following prison service training actions were undertaken: 
- 14 training actions for 463 prison guards in areas ranging from initial training to legal and ethical training and human rights.

In 2009, the "Other transfers" line in the budget of the Commission to Coordinate the Fight against Drugs (CCCD) was 100 percent executed, compared to the established target for 2009 of $>95$ percent.

In relation to corruption, the number of cases and processes investigated by the Public Prosecution Department of the Republic is as follows:

- Public Prosecution Department of the Republic, Praia jurisdiction: $7^{4}$

- Public Prosecution Department of the Republic, São Vicente jurisdiction: $6^{5}$

- Public Prosecution Department of the Republic, Sal jurisdiction: $2^{6}$

- Draft laws to combat the financing of terrorism and on state seizure of property were finalized and are ready to be sent to the National Assembly.

A total of 11 legal advice centers (Casas do Direito) were created in 2009. In terms of property registration, the Casas do Direito that are operating have played an important role in government reform, providing crucial information to people requiring it, in a nonbureaucratic way.

\subsubsection{Migrations}

\section{Strategic orientations:}

- Efforts made by central and local authorities to improve knowledge of the communities of origin of migratory flows and to define measures and productive activities to encourage the respective populations to stay.

- Recognize the past and present of the immigration situation in Cape Verde, analyzing decisive aspects that condition it, in terms of legal provisions and the internal and external environment.

- Obtain opinions on national immigration policy from institutions, partners, and economic and social forces, interest groups, specialists and personalities.

- Make a survey of obligations assumed by the State of Cape Verde at the international, regional, and community level, and compile all current legislation in the country

\footnotetext{
${ }^{4}$ Six cases pending and one case with formal prosecution.

${ }^{5}$ Six cases existing from 2000 to 2010 , all of which in the investigation phase.

${ }^{6}$ Prosecuted and convicted.
} 
relating to the entry and stay of foreign citizens in the country, the regime for hiring foreign labor, and management of immigrant flows.

\subsubsection{Emigration}

- It is estimated that the annual average rate of emigration will drop to 1 percent in the period 2005-2010, compared to the 1.5 percent levels recorded in 1990-1995, 19952000, and 2000-2005 (UNPF, ${ }^{7} 2009$ ). There is no accurate knowledge of the number of Cape Verdeans living and working abroad; the only certainty is that the United States and Portugal are the preferred host countries.

\subsubsection{Immigration}

- In June 2009 , an interministerial commission was set up to propose bases for immigration policy aimed at the following: (1) combating clandestine immigration and the employment of illegal labor, and the socially degrading situations that these phenomena can entail; (2) effective management of migratory flows; and (3) effective and harmonious integration of migrants into Cape Verdean society.

- The most recent figures show that the immigrant population increased by about 20 percent between 1991 and 2005. The trend is for that growth to continue, to reach a level of 12,035 in 2010. Figures on residency authorizations from the DEF (2008) show that the main countries of origin are in Guinea-Bissau (19.8 percent), Portugal (13.8 percent), China (13.7 percent), Nigeria (11.5 percent), and Senegal (11.3 percent).

The Centre for Research Development on Migrations, Globalization, and Poverty $\left(\mathrm{DRC}_{2007}\right)$ shows that 76 percent of immigrants in Cape Verde come from Portuguese-speaking (PALOP) countries. ${ }^{8}$

The actions undertaken by the interministerial commission were:

- Survey of legislation on immigration;

- Diagnostic assessment of the functioning of public institutions that work on migration issues;

- Preparation of projects and financing proposals (resource mobilization);

\footnotetext{
${ }^{7}$ United Nations Population Division.

${ }^{8}$ Angola, Cape Verde, Guinea-Bissau, Mozambique, and São Tomé and Principe.
} 
- Mobilization and financing to produce the study "Imigração em CV" [Immigration in Cape Verde], which forms the basis for developing the national immigration policy;

- Mobilization of technical assistance under the MIEUX initiative of the International Centre for Migration Policy Development (ICMPD), to formulate the national strategy on migration, which will be completed in July 2010; and

- Development of the studies: "The migratory profile" of the International Organization for Migration (IOM); and "Identification of Cape Verde's needs in terms of asylum and migration" of the ICMPD, an initiative by the Netherlands.

Under the Partnership for Mobility declaration signed between the European Union and Cape Verde, and with the aim of managing migratory flows, activities were undertaken in relation to promoting legal immigration and combating irregular immigration, promotion of training, and encouragement for monetary and skill transfers, promotion of circular migration and return, to reduce the impact of the emigration of highly skilled individuals and to contribute to development in their country of origin.

Next stages - The challenges to be overcome in terms of good governance for the next five years require priority for the implementation of a realistic public administration modernization program that is also consistent and coherent, at the service of citizens and firms, and promotes democracy, economic development, and modernity. At the institutionalorganizational level, the government is determined to ensure a strengthening and consolidation of institutions, deepening of democracy, and the forging of broad consensus on subjects of major interest to the country. It is also determined to have approved and implemented the charter on the incumbents of political posts to make them properly accountable for the management of public affairs.

In terms of consolidation of democracy and the rule of law, actions to be undertaken aim at implementing the plan to strengthen State authority and promote citizenship; and the holding of the forum on strengthening of citizenship and participation.

\subsection{Pillar II - Human Capital}

Human capital development is the main pre-requisite for achieving the objectives set for economic growth, integration into the global market, and mitigation of poverty.

\subsubsection{Education}

\section{Strategic orientations:}

- Quality, shifting the focus to the process and learning outcomes 
- Equity, involving a high degree of institutional sensitivity to local and social differences in access to education

- Social and economic relevance, leading to a constant demand for social and economic gains

- Responsible and progressive decentralization of the management of the education system according to the potential and capacities of local authorities.

- Social partnership, through support for private initiatives at all levels of education.

Ever since its independence, Cape Verde has endeavored to improve the quality of education it provides to its citizens. The reforms implemented over the last 15 years generated far-reaching changes in the education system, resulting in better adaptation to the economic and social development needs, which is the medium-term objective.

The education system is facing the crosscutting challenge of implementing a national learning assessment system to produce indicators of what is effectively being taught and learnt, together with standardized attainment tests and consequent establishment of quality standards.

The performance of the education system remains high in terms of coverage, parity, school performance (percentage graduation rate, repetition rates, dropout, trained teachers), budgetary execution, etc., and the outcome indicators adopted have been satisfied.

Basic education is universal and compulsory, covering six years of schooling. The secondary school population has been shrinking since 2000/2001, and is expected to stabilize in the next few years, which could mean a decongestion of this level of education and the possibility of reallocating resources to improve quality. From 90,640 students in 2000/2001, the enrolment dropped to 73,548 in $2008 / 2009$, reflecting a falling demographic trend in the age range covered by this level of schooling.

Progress achieved in basic education:

- Both the net and gross enrolment rates have improved, from 53.9 percent and 65.0 percent in 2000/2001 to 62.0 percent and 71.3 percent in 2008/2009, with a slight bias in favor of girls with figures of 67.0 percent and 76.7 percent in those years.

- The proportion of trained teachers rose from 67.2 percent in $2000 / 2001$ to 86.5 percent in 2008/2009;

- The average number of students per class fell from 28 to 24 in that period; 
- The basic-to-secondary school transition rate rose by 12.2 percent from 70.7 percent in 2000/2001 to 82.9 percent in 2007/2008. Most students graduating from basic education continue their studies at the secondary level. The rapid expansion of secondary school enrolment led to improvements in school facilities, including the construction and repair of more schools and classrooms.

Nonetheless, a number of regional asymmetries persist.

Secondary education is of a professionalizing nature and currently includes the training of basic education teachers provided by the Pedagogic Institute.

- Scientific research has a research policy and acquired equipment and bibliographic materials.

- The Pedagogic, Technology, and Research Service was created; and

- The self-assessment policy was instituted to monitor the quality of teaching offered by private universities.

In terms of economic and social relevance, and although the supply of university and polytechnic courses does not satisfy domestic demand (exacerbated by the reduction in opportunities for training abroad), efforts have been made to expand the range of new courses, including postgraduate and masters programs, with a view to addressing the country's development priorities.

The adult vocational education segment - literacy training and other permanent actions to develop employable vocational skills - includes a wide range of training activities, including tourism, arts and crafts, civil construction, mechanics, electricity, and new technologies.

In relation to social partnership, the Cape Verdean Social-School Action Institute (ICASE) has been providing socioeducational support in a variety of forms, such as school transport, scholarships and course fee subsidies, hot meals, and implementation of the school health program, at all levels of education. Those actions can also be undertaken with participation by private institutions, with which ICASE signs agreements, strengthens existing partnerships, and obtains sponsorship from firms, community associations, and public and private teaching institutions, aimed at expanding the range of socioeducational support provided for students of basic, secondary, and higher education, which have exceeded the targets set. 


\subsubsection{Employment/vocational training}

Strategic orientations:

- Design and building of an integrated education/training/employment system

- Development of a National Qualifications and Vocational Skills System

- Establishment of permanent courses to provide initial vocational training.

- Promotion and development of continuous training, with participation by firms and other social partners involved in vocational training.

- Creation and implementation of a Permanent Initial and In-service Training Center for trainers and tutors

- Organization of a statistical information system for vocational training, specifically through the creation of a Vocational Training Observatory.

According to the 2008 Socioeconomic Survey, the total economically active population amounted to 119,857; the number of people in employment was 163,380 (51.4 percent men; 46.1 percent women) and the total number of unemployed was 35,745. The unemployment rate in 2008 was 17.8 percent, an improvement on the 2007 QUIBB figure of 21.7 percent, but still very high in relation to the development dynamic desired for the country.

Consequently, employment was defined as a key development policy objective, involving the coordination of all policies targeting the creation of productive employment. In a demonstration of its firm intent to combat unemployment, the government:

- Allocated a total of CVE 1.0 billion in the 2009 State budget.

- Continued to implement its national employment policy.

Latest results:

- An average of 2,384 jobs were created per year between 2000 and 2008. Job creation was 3.5 times higher than the creation of unemployment.

Vocational training for employment and social inclusion:

- The supply of technical and vocational training services reflects the strengthening of institutional capacity in local training centers, restructuring of the IEFP, and the assignment of responsibilities to coordinate training actions, monitoring and 
evaluation, integrated planning, reactivation of the Employment and Vocational Training Support Fund, and joint coordination of the sector with partners.

The emphasis on employment and social inclusion can claim significant achievements in terms of the creation of the National Qualification System Coordination Unit and the Professional and Vocational Guidance Unit, and the establishment of four training units in secondary schools.

Achievements in 2009 include:

- Youth Apprenticeship Program

- Promotion and development of training actions in the vocational training hubs

- Vocational training and technical education -professional component

- Support for the National Employment and Vocational Training Program

- Professional Practices Program

- Citizens Soldier Program

- Training of trainers

- Execution of the Strategic Vocational Training Plan

- Hotel School (Praia)

- Vocational Training Center of Praia, Variante; and Fogo/Brava

- Implementation of the Integrated Employment and Vocational Training System

First job subsidy — Professional practice: This is another active employment measure mainly targeting young people with vocational training. The agreement aims to financially strengthen the Professional Practices Program and help to increase the number of young people entering the labor market. Execution set to begin in 2010.

- The agreement was signed between the National Employment and Vocational Training Support Program (PAPNEF) and the IEFP. It aims to finance the implementation of the First Job Subsidy project.

Statistics produced by Employment Centers show a significant increase in the number of jobseekers, although its performance and mode of operation need to be reassessed. 
- In 2009 , there were a total of 962 people registered, 318 more than in the previous year, showing a greater acceptance by the population of the services provided by the centers. The heaviest demand for employment was recorded in the employment centers of Mindelo and Praia. The total number of jobs offered in 2009 was 80.

As part of a plan to create a Social Development Observatory to within the Ministry of Labor, Family, and Social Solidarity, the sector has decided to set up an Employment and Vocational Training Observatory, a very important instrument for collating and analyzing data on employment and vocational training, which is urgently needed and also strategic for the sector.

Achievements:

- In December 2009, a large meeting was held in Praia to publicize the employment and professional training observatory.

Stages to be overcome: Ongoing challenge to link/articulate education with the vocational training system and adapt it to the business reality and the labor market, notwithstanding measures that have been implemented. The general vocational skills deficit is another challenge and one of the decisive factors for poverty, particularly in rural areas.

\subsubsection{Health}

\section{Strategic orientations:}

- Reorganization of the National Health Service

- Provision of health care that is accessible and encompasses all dimensions of the human being, capable of monitoring illness or risk episodes. This implies the organization of services, particularly for primary care

- Implementation of the strategic human resource development plan

- Review and adapt the network of structures in their diversity of type and competencies

Health indicators are not good in general, and there is a high threat of relapses and major challenges to reverse them as and when they occur.

With regard to integrated surveillance of transmissible diseases and AIDS: 
- 93.7 percent of pregnant women used antenatal services and benefited from the counseling and pregnancy test in 2008, far above the baseline of 13 percent (IDSR_2 - 2005) and the 40 percent projection contained in the official documents.

- No healthcare institution offering antiretroviral treatment suffered a stockout of antiretroviral drugs.

- 22 percent of private firms with 30 or more employees (90 out of 85 ) are investing in activities to support the national HIV/AIDS strategic plan 2006-2010 according to the CCS-AIDS, above the 10 percent level envisaged.

The under-fives mortality rate reached a level of 25.7 per thousand live births in 2007 , compared to the benchmark level in GPRSP II of 28.6 per thousand. In 2008, the rate rose to 28.1 per thousand.

- The number of deliveries attended by qualified professionals (doctors and nurses) in health structures in 2005-2008 rose from 8,773 to 9,475. In relative terms, the figures were 75.9 percent (2005) and 74.6 percent (2008), according to data provided by the health delegations, and the Regional and Central Hospitals. The baseline of 74.4 percent set for 2007 was a slightly exceeded in 2008 .

- The number of reported cases of malaria per 100,000 inhabitants in 2008 was 4.0, compared to 4.5 predicted for that year.

- The incidence of tuberculosis per 100,000 inhabitants in 2008 was 39.2, representing a very positive trend compared to the 56 envisaged in GPRSP II for that year. The trend has been downwards since 2003, when 65 cases were registered.

- 29.0 percent of women between 15 and 49 years of age, who are married or living in de facto union, used some method of contraception in 2008.

The dengue fever outbreak in the last four months of 2009, required robust action to combat the epidemic; and this received strong support from the international community and raised the need for an improvement in the country's phytosanitary situation, especially in the city of Praia. Nonetheless, the national health service responded to the epidemic immediately, with the result that Cape Verde now is publicizing its experience in major world forums on dengue fever, having held a conference on the subject in the country.

Nonetheless the country needs to be better prepared to deal with any future crises. The economic and financial impact of the dengue fever epidemic in Cape Verde in terms of tourism and public health remains unknown.

A new indicator was added to the sector performance matrix, focusing on health conditions and a healthy environment. This indicator relates to efforts to combat the larva stage of the 
mosquito vector of malaria, and has been incorporated in the strategic plan for preelimination of malaria.

\subsubsection{Health and sport}

\section{Strategic orientations:}

- Improvement of conditions for participation by young people in the country's social, political, economic, and cultural life

- Deepening and strengthening of policies to upgrade human capital, prioritizing the role of youth in development opportunities.

Determined to deepen and strengthen its policy to upgrade and involve young people and women in the socioeconomic development process, the government has been providing better conditions for their qualitative participation in the country's social, political, economic, cultural life.

- In 2009, as part of the promotion of citizenship and support for young people, 15 youth centers are operating, along with several telecenters, which promoted the integrated development of adolescents and young people, particularly in terms of reproductive health and economic and social participation.

In terms of human and institutional capacity building, actions aimed at:

- Production of educational material (e.g. "Agenda Jovem" [Youth Agenda] with a print run of 3000 copies);

- Training of young people (from these centers and telecenters, and volunteer youth) and associative and community leaders on sexual and reproductive health, HIV/AIDS, drugs, methodologies in health education; counseling for young people; associativism and volunteer action, with a view to providing a better service to young people and the population at large

- Computer equipment was obtained for four offices to support income-generating activities; school, vocational, and professional guidance, and the evaluation of projects in the various youth centers in the different concelhos (counties).

- Training equipment was also obtained to equip the reproductive health clinical assistance service in a number of localities.

- Nonetheless, the strategic plan for youth and the operational plan have not yet been updated. 
In terms of participation in active life - a crucial aspect of the engagement of young people — the following actions were undertaken:

- 13 training events on income-generating activities (e.g. garment making, cooking) in the country's various concelhos.

- Offices were opened to support income-generating activities, school, vocational, and professional orientation, and project evaluation in the youth centers of Calheta de São Miguel, São Salvador do Mundo, São Filipe, Ribeira Brava de São Nicolau; and

- Support and was provided to young mothers through income-generating activities in entrepreneurship and development of business and accounting plans.

In terms of the decentralization of activities in the youth centers, two mobile centers were obtained for the islands of Santo Antão and inland Santiago.

The centers facilitate participation in IEC activities, training events in various areas, and information technologies for young people from disperse and isolated localities not supplied with electricity. Also in terms of the functioning of youth centers, the following activities were carried out:

- Inauguration of the youth center on the island of Maio. This gave young people a multipurpose facility capable of providing a very wide range of services and support.

- Joint activities undertaken in 2009 with institutions such as the health delegations in several urban neighborhoods on prevention of influenza A and the fight against dengue fever. With the ICCA to commemorate the International Day of the Child and for psychological counseling and registration of children. With the Directorate General of the Environment, in campaigns for cleaning, painting and rehabilitation of homes for poor families on the occasion of World Environment Day. With the CCCD in lectures, training of trainers for youth leaders and volunteer youth from the CEJ of Praia, etc. With the Cape Verdean Solidarity Federation in collecting food for poor families, rehabilitation and painting of homes to commemorate the world today for the fight against AIDS and International Volunteer Day.

- Offices set up in the youth centers of São Vicente, Praia, and Santa Cruz are working full-time, because there are technical staff available. The others are working with outside technical support.

As a results indicator, 216 young people from several other concelhos, mainly mothers, were trained in income-generating activities and entrepreneurship. Twelve young mothers obtained support to set up their own business. Young mothers also benefited from training courses, 20 from São Domingos, 20 from São Vicente, and 15 from Ribeira Brava on São Nicolau. 
In addition, a Communication Program is being implemented to disseminate and raise awareness of activities related to youth ... and the inauguration and functioning of Pousadas de Juventude and the Cartão Jovem program.

In the sports area, the most important events in 2009 were:

- The basic law on the sport system was reviewed and is being circulated among national partners.

- The process for producing the national sports card was set in motion but it will only be initiated in January 2010.

- All statutory contributions to the international organizations to which Cape Verde is affiliated were brought up to date, except for the Supreme Council for Sports in Africa (CSDA).

- In cooperation with the local councils, schools and private entities, a number of sports infrastructures were refurbished, upgraded, or given significant improvements for users and

- Today all the islands, except for Brava, have a municipal stadium with synthetic grass.

- Construction of the National Stadium is set to start in February 2010.

- Funding was provided to purchase materials and equipment for the Sports Medicine Centre of Praia, and the Portuguese government offered a variety of sports materials for sports initiation schools, together with a package of books and magazines.

The following actions were undertaken for continuous training of sports agents:

The training of young trainers in handball and basketball, targeting sports initiation schools from the Sports Regions of North and South Santiago and the MEES delegation in Praia. The trainer training event was held (Mindelo, October 2009) for physical education teachers and trainers in various sports. Sports agents and DGD officials received a study scholarship for higher training in the country in the area of physiotherapy (2) and physical education (3); law (2); social services (1), accounting and administration (1), and economics (1), in partnership with higher education institutions. A training session was held for handball referees in Brava (trainees from Fogo also participated); and Santo Antão held a training session for referees and trainers in handball and another on "Planning for a sporting season" for sports agents in Santo Antão. 


\subsection{Pillar III-Competitiveness}

Promotion of dynamic sectors of the economy and improvement of the standard of specialization of the economy.

\section{Strategic orientations:}

- Development of competitiveness in the tourism sector

- Support for national private investment

- Internationalization of services and their competitiveness

- Modernization and internationalization of the financial system

- Integrated development of the rural world

The government is investing heavily in optimizing key factors of global competitiveness that represent important competitive advantages for attracting private investment into the country, highlighting aspects linked to the transparency of government operations, promotion and protection of private investment, property, freedom and civil rights, prevalence of the law, and the right to personal security. The country's global competitiveness is thus based on the fundamental pillars of good governance and macroeconomic stability.

\subsubsection{Agriculture $^{9}$}

The medium-term goal for agriculture is to develop an integrated agro-forestry-grazing system with intensive and diversified operations, and to add value to domestic agricultural products.

- The management of river basins as a territorial management unit, involving the various stakeholders (associations, private individuals, State and non-State institutions), bearing in mind the infrastructures produced, agroforestry interventions, and the measures to be taken permanently as the basic policy orientation adopted for the sector.

Projects for organization and upgrading of the Picos and Engenhos water catchment basins were evaluated, at mid-term, by an external entity.

9 P.A.G.I.R.E - Cabo Verde Revisto. Volume I Diagnóstico - March 2010. Rural Engineering Report 2009. 
- Soil conservation activities made it possible to organize a total area of 52 ha (77.0 percent) in the two catchment basins, compared to a projection of 67.5 ha. Global financial execution is $93 \%$, distributed as follows: the $95 \%$ rate for the Picos catchment basin, and $89 \%$ for the Engenhos catchment basin.

- Several water capture levies and torrential rain correction and underground dams and gabion walls were constructed. Drilling, bore-hole equipment and pumping tests have been undertaken in two catchment basins, and five reservoirs were built, which will attain their full capacity in 2009. Two supplementary reservoirs are under construction with capacities of 2,000 and 2,500 $\mathrm{m}^{3}$ in the Engenhos catchment basin, with the remaining funds from the loan. The construction infrastructures envisaged in the project made it possible to mobilize $5,252 \mathrm{~m}^{3}$ of water per day. The water captured in the reservoirs and levies remains for seven months after the rainy season (October to April) while the wells provide running water.

The quantity of water mobilized in the two catchment basins makes it possible to irrigate a total area of 146 ha, encompassing around 730 farmers and benefiting 3,650 family groups.

The forestry subsector in 2009 targeted actions on promoting sustained and integrated management of agro-forestry-pasture resources in accordance with agroecological and socioeconomic conditions. Projects executed included:

- Creation of new forestry areas;

- Organization and maintenance of forest boundaries;

- Undertaking of a national forestry inventory;

- Protection of natural resources on the island of Fogo phase II-extension;

- Capacity building in terms of awareness raising, prevention, management, and combat of forest fires (TCP/CVI/3101 -D).

To achieve the objectives contained in the agriculture strategy, the Agriculture and Forestry Directorate (DGASP) prepared:

- The projects "Sustained management of forestry areas in Cape Verde", and "Jatropha curcas in Cape Verde - Island of Fogo" which will start execution in 2010.

- Project documents were produced relating to the conservation of Atlantic Phoenix and environmental recovery of characteristic landscape of Boa Vista, which were then submitted for external financing.

Studies are scheduled to be undertaken of the Ribeira Grande water catchment basin on the island of Santo Antão, financed through a sinking fund by the Arab Bank for Development in Africa (BADEA), and the catchment basins of Sorno, Fajã de Água and Ferreiros on the 
island of Brava, funded by the European Union. The following projects are also expected to be prepared:

- Integrated torrential correction levies in the Ribeira Brava high traffic basin;

- Torrential correction levies in the catchment basins on São Vicente;

- Agricultural development of the island of Boavista;

- Submit the Calhau project for financing.

\subsubsection{Fisheries}

The major medium-term objective for the fisheries sector is to increase its contribution to GDP, which was small between 2004 and 2007, averaging 0.6 percent.

Fisheries employ about 5 percent of the active population, which is below the 12 percent per year envisaged in the sector matrix for the GPRSP horizon. To achieve the objectives, the sector has undertaken the following actions in 2009:

- Actions to combat illegal fishing.

- Start of implementation of the satellite vessel control system (VMS)

- Preparation of the plan for the management of fishery resources and review of the ZEE inspection plan.

- Continuation of the organization of fishing communities into associations and continued training in the management area.

- Modernization of cold store infrastructures.

- As part of steps to increase health security, construction of the official laboratory of fishery products is scheduled for 2010.

- Maintenance of the transfer of fish catches in ports.

- Updating of information on fishery stocks (shrimp and crab).

- Preparation of two projects to evaluate the water shrimp and crab stocks in Santa Luzia and S. Vicente.

- Campaigns to raise public awareness of the need to conserve and protect marine turtles, inspection of beaches involving fishing communities, public and private institutions and organized civil society. 
The execution of the intersector environmental plan for fisheries has performed well.

- Approval of the Fisheries Resource Management Plan for 2010 B.O. I series No. 18 of May 4 2009;

- Launch of the compilation "Fishery legislation of Cape Verde" second volume;

- Signing of agreements with CETMAR, to strengthen the inspection and monitoring of fishery activities in the exclusive economic zone;

- 32 percent increase in fishery exports, and 2 percent reduction of imports thereof; and

- An increased production of ice in existing units and the creation of new units.

\subsection{3 $\underline{\text { Tourism }}$}

The medium-term objective, contained in the global matrix, calls for improvements in the efficiency of tourism promotion and in the quality of the products and services supplied. The strategy adopted is very wide ranging and sustainable with greater local content. The sector strategic plan (PEDTCV2010-2013) was approved in December 2009 in the Council of Ministers, and is currently being disseminated.

As suggested, the plan considers the environment as an asset, defends the promotion of ecotourism, particularly in natural parks and protected areas created, and prioritizes the minimization of potential environmental impact arising from tourist activities.

The country's tourism legislation is currently undergoing a review, and this is expected to be approved at the end of 2010. Also, on the institutional front, the sector now has a DirectorGeneral, which fills a gap that previously existed and gives a new dynamic to the sector.

According to the INE, and data from the survey of guest movements, roughly 333,354 guests entered hotel establishments, representing a 6.5 percent increase on the previous year's figure. This indicator is below that forecast for $2009(370,000)$ in the GPRSP II framework, which could be explained by the international crisis. The island of Sal continues to receive the largest number of guests ( 57 percent of the total).

\subsection{4 $\underline{\text { Services }}$}

In the support services area, the competitiveness of services provided through the 11 international financial agencies operating in the country has improved, which is above the 2011 target set in the framework and was achieved before 2009. The commercial register contains a total of 20 information and communication technology (ICT) firms, set up in 2009. 
Most of these are established in Praia and work in the areas of fixed-line, wireless, and satellite telecommunications. The target for 2009 (6) was comfortably surpassed.

\subsubsection{Private Sector}

Empowering the private sector as the leader of economic development is the major mediumterm objective. The authorities concur with the data from Doing Business, which recommend an improvement in the business climate and confirmation of the private sector in the country's economy, thus contributing to growth and rising employment indices. In this framework, significant progress has been made, particularly as a result of the entry into force of the citizens bureau (Casa do Cidadão) in Praia and the mobile citizens bureau in North Santiago.

As a result, facilities were created for doing business, making it possible to consolidate the private sector's role as the leader of economic development. The following gains were achieved:

- The business and entrepreneurship environment improved with the reduction, alteration and elimination of several processes and procedures for starting up businesses, and doing business, which resulted in gains in the number of transactions undertaken, costs and time.

- On the fiscal front, the corporate income tax (IUR) rate was lowered from 30 percent 25 percent; and the personal IUR rate was lowered from 45 percent to 35 percent.

- Computerization of the fiscal register including the assignment of a taxpayer identification number (NIF), is now a reality;

- Publication of tax information guides both online and in the Yellow Pages;

- Contractualization of the payment of tax debts;

- The process of closure, suspension, and bankruptcy of businesses has specific guidelines in the "Guidelines on business closure procedures", and will be included in the same automatic system for setting up firms.

In relation to the property register, the property cadastre regime, defined by Decree Law 29/2009, BO No. 33 of August 17, came into force, the ad valorem system was altered to allow for the reduction of the costs of notary and registration procedures (Decree Law 70/2009, BO No. 49 of December 30), and the island of Sal undertook a pilot exercise consisting of establishing the integrated product of simplified 48 hour property registration (Linha Azul/ Casa Pronta). 
On investor protection, a proposal to join the International Centre for the Settlement of Investment Disputes (ICSID) was put forward, and will be presented to the Council of Ministers and National Assembly.

Cape Verde is 147th in the World Bank's 2009 "Doing Business" ranking; but it is ranked fourth in the region following Ghana, Nigeria, and Gambia. This performance is below the target of 2009 (100) but is justified partly by the adoption of a new evaluation methodology; and no backsliding in relation to ongoing public sector reforms are responsible.

Future stages:

There is clear awareness of the need to introduce additional measures for setting up businesses, hiring workers, obtaining credit, protecting investors, external trade, and business closure.

In terms of innovation, the country's performance still needs to be improved and the labor force strengthened, which lacks "capacity building"; and also better access to financing for firms.

The new global economy, in which success depends largely on the quality of the country's institutions and the creativity and entrepreneurship of individuals, requires Cape Verde to create a more robust capacity to compete in the global market.

\subsubsection{Trade}

Upgrading national production to meet the needs of the population and the integration of Cape Verde into the world economy are strategic orientations for the sector.

The business environment for domestic trade has improved substantially particularly in 2009 as a result of:

- The entry into force of various legal provisions regulating trade.

- Issues such as the prevention and suppression of money laundering, economic crimes and crimes against public health, control of security and quality of food products and animal feed, marketing prices for oil products, consumer protection, and the regime for approving commercial establishments, were all legislated on.

On the international trade front and to improve Cape Verde's participation in it, Parliament used its constitutional powers to provide legislative authorization for the government to approve the new Customs Code (Law 46/VII/2009, B.O. No. 46), which will include issues regulated by the Customs Organic Charter, the Customs Disputes Law and legal amendments thereto. In terms of international treaties and agreements affecting customs issues to which the country is affiliated, the agreements of the Economic Community of West African States (ECOWAS) on the circulation of goods in the community space, the treaty forming the 
WTO, and multilateral agreements to which it is party (without prejudice to the provisions of the Protocol of Cape Verde's Accession to the WTO), are parameters governing the country's Customs Code.

\subsubsection{Industry}

The basic aim is to develop an industrial sector that is integrated into the country's human development policy and respectful of the environment. Environmental protection is thus one of the key concerns of industrial activity.

The national productive base has been strengthened with the creation of new industrial units. In 2009, 51 new industrial units were set up as part of a rising annual trend. Nonetheless, the annual growth rate is not high. For example, in 2009, five more new industrial units were created than in 2008 .

Most of the country's industrial units are in Santiago (35) and São Vicente (6). The islands of Sal, Santo Antão, Boavista, Fogo and Maio were also included.

- In 2009 , the industrial sector created 880 new jobs, slightly down on the 2008 figure of 1,230 .

- The jobs are in industries related to civil construction and public works, and the manufacture and sale of construction materials.

- The sector contributed 12.6 percent of GDP in 2007, the latest year for which data are available.

Industrial and economic growth entails potential environmental damage, which if not brought under control could grow to irreversible proportions. With measures governing the construction of new industrial parks, review of the ecological tax, and development of the plan of action for sand extraction, the Ministry of Tourism, Industry, and Energy has always sought to safeguard environmental protection, which it sees as a crucial factor for social cohesion.

In relation to permits for firms producing inert materials and the agreement on the supply of sand to the domestic market, the permit process basically requires the presentation of an environmental impact study.

The agreement for the supply of sand to the domestic market signed with Central de Britagem Cabo Verde, SA (CBCV) and in force since February 2006, to mitigate the extraction of sand from ocean beaches, which is considered an illegal practice with a negative environmental impact, is not being complied with and will soon be revoked. Work is currently ongoing on other possibilities for "supplying" the domestic market, involving exemptions for sand importing firms. 
Trade is the most dynamic business segment in terms of the number of enterprises, employment, and business volume among small, medium-sized, and large firms. Small and medium-sized firms represent about 90 percent of the country's enterprises and generate roughly 39 percent of all jobs. Large firms represent about 10 percent of the total number but account for the bulk of economic activity of the country's business sector: about 69 percent of business volume and over half (61 percent) of employment.

Small and medium-sized firms have difficulties accessing finance, whereas the greatest obstacle for larger firms is the inadequate skill level of their workforce.

In terms of an economic environment favorable to job creation for vulnerable population groups, there has been a robust business dynamic leading to a considerable growth over the last 10 years. The third Business Census of 2008 (INE) recorded the existence of 8,716 firms.

\subsubsection{Regulation}

Developments on the regulatory front include the following:

- Presentation of the plan for technical and regulatory convergence as part of the special partnership with the European Union.

- Approval of the benchmark plan to strengthen regulation and inspection;

- Launch of the process for reviewing the statutes of agencies of regulation and general inspection of economic activities; and

- Creation of the Competition Authority.

Among other measures to be implemented in the trade sphere, the government intends to institute strengthened and coordinated inspection of firms by institutions such as the DGCI, IGAE, and DGT.

\subsection{Pillar IV - Economic Infrastructure}

The public investment program aims to eliminate the greatest infrastructure constraints to economic development and increase the economy's long-term potential growth.

\subsubsection{Infrastructures and transport and communication}

\section{Strategic Orientation:}


- Consolidation of the dynamic of infrastructure building and modernization of the sector

The medium-term objective is to guarantee the circulation of goods and people in conditions of safety. Roads need to be in a good state.

Infrastructures are essential for structuring national territory; they affect the spatial distribution of the population and the development of population clusters; and they ensure the mobility of people and goods, facilitating trade and providing access to social and administrative equipment and services.

In terms of road infrastructures in the period 2001-2009:

- $252.7 \mathrm{~km}$ of roads were built and refurbished, 96 percent of which were paved with asphalt and 4 percent with concrete.

- The package of works financed by the Millennium Challenge Corporation (MCC) were completed and inaugurated, representing the construction of about $54 \mathrm{~km}$ of main roads.

- The Tarrafal - Praia Branca - Ribeira Prata highway was built;

- Improvements were made to $26 \mathrm{~km}$ of the Ribeira Brava - Tarrafal highway on the island of São Nicolau. Unfortunately, between August 24 and September 27, 2009, the island was hit by exceptional rainfall that caused major damage in Vila da Ribeira Brava and its access roads.

- The two variants of the Praia - S. Domingos highway were finished, as well as the road network in Praia.

- There are various road works in several of the country's concelhos, in particular Anel do Fogo, which involves a high investment.

In the area of road maintenance, the road maintenance tax (TSMR) began to be charged in January 2009, marking a new era for the Autonomous Road Maintenance Fund, which has collected CVE 229 million.

Inter-island sea links are being operated by private firms under principles of freedom to set up business and free market access.

- The Ministry of Infrastructures, Transport, and Telecommunications (MITT) has introduced service concession contracts on a number of routes such as Praia/Fogo/Brava, Praia/Maio/Praia, Praia/São Nicolau/ São Vicente, and Praia/Sal 
Rei/Palmeira, to allow for provision of the minimum services needed to promote the political objectives of cohesion and equity across the country.

- Construction of the air traffic control center began and is expected to be concluded by mid-2010.

- The maritime signaling project was prepared; and the terms of reference and the bidding documents were discussed for the project to modernize maritime navigation systems and their linkage to control centers.

- Terms of reference and bidding documents were also prepared for the coastal management study, and a tender will shortly be launched to carry this out.

- The first phase of the VTS system, for which the equipment is in the country awaiting assembly, will be implemented shortly.

Port sector activity has grown vigorously with the start of execution of the major port infrastructure program, which is expected to be completed in 2012.

- Works to modernize and expand the port of Praia are currently under way, which consist of building a cargo terminal in the Achada Grande zone, constructing an access road, and refurbishing the No. 2 pier. The tender for execution of the second phase has been launched and construction has begun of the support building for the port of Praia.

- Expansion works have begun at the port of Palmeira, and are proceeding at a good pace thanks to the mobility of equipment on the ground.

- Expansion works at Porto Novo, and modernization works at Porto de Sal Rei and Porto de Vale dos Cavaleiros on Fogo and Porto de Furna on Brava are in the bidding and bid analysis phase.

- Container scanners have been obtained for the following ports: Porto Grande de São Vicente, the port of Praia and the port of Palmeira on the island of Sal.

- The process of obtaining a patrol vessel for the inspection of ports and Cape Verde's exclusive economic zone is currently ongoing.

Private enterprise has become involved in airport development for the first time, by participating in the financing of upgrading the Boa Vista airport to receive international flights.

In 2009, airport infrastructure works continued, in particular:

- Remodeling, adaptation, and adjustments in the São Vicente airport;

- Launch of the tender for expansion of the parking area at the Boa Vista airport;

- Expansion of the Maio airport terminal, for which the works have already been completed; and 
- Construction of a VIP lounge at the Praia airport.

\section{Communication}

The strategic objective for the communications sector includes a review of the costs model, a review of pricing on rented circuits and interconnection services, the introduction of new operators in broadband radio, a review of the concession contract, and the laying of another undersea cable.

According to "Cabo Verde em números" [Cape Verde in numbers], published by INE in 2006, 67 percent of family units have a fixed/mobile telephone; 70 percent have radio, and 62 percent television. Telephone density was 15 per 100 inhabitants in 2005 .

\subsubsection{Land Management}

\section{Strategic orientations:}

- Implementation of land management tools such as the Basic Law on Land Management and Urban Development Planning and the Expropriations Law

- Support for municipalities in preparing their individual urban development plans.

The medium-term objective adopted is to improve land management and the cadastre.

Success in implementing land management policies and programs depends on the articulation of actions by the various organizations with responsibilities in this area, particularly the Directorate-General of Land Management and Urban Development, Cabo Verde Investimentos, and the municipal councils. In recent years, significant gains have been made in terms of environmental policy and land management, despite persistent constraints.

Most of the projects are included in the PANA_II, while the Directorate-General of Land Management and Habitat (DGOTH) in 2009 has undertaken activities to define land management tools based on public land management policies. In the area of planning and preparation of land management and urban development plans, final approval for land management tools has been delayed.

- A Municipal Master Plan (PDM) was approved and published in the Official Bulletin in 2009, and another 15 PDMs are currently being prepared. The PDM for Porto Novo is about to be approved; the PDM for Brava is in the characterization and diagnostic phase; the PDM for Mosteiros is in the phase of analysis of the plan proposal; the PDM of Paúl is in the public consultation phase; and the PDMs of São Filipe and Santa Catarina on Fogo are currently being drafted. 
- Consequently, in 2009, municipal development plans continued to be developed: nine PDMs; and seven urban development plans (PDUs) in Santiago. There was excellent performance in terms of the execution of intersectoral environmental plans, in particular for land management. São Domingos and Sal have land management plans approved and published.

- With the preparation of these PDMs, by late 2009 it is expected that 59 percent of the country's municipalities will have begun to prepare their land management tools, which will make it possible to overcome problems such as sanitation, water supply, and agricultural production.

- Of the three regional land management schemes [Esquemas Regionais de Ordenamento do Território - EROTs], which are a DGOT responsibility, the public consultation process was concluded for the EROTs of Santiago, Santo Antão, and Fogo as foreseen in the Basic Law on Land Management. The São Nicolau EROT is in the phase of analysis and presentation of the characterization, diagnostic, and scenario development.

- A summary report was produced with a view to improving the proposals of the EROT territorial model.

In relation to the legal framework:

- A new basic law on land management was passed;

- The Law on Soil and Expropriations, the Law on Cartography, and a Framework Law on the Cadastre were all passed.

Technical assistance was also provided by the DGOTH in the urban development area of the municipalities (e.g. Tarrafal on São Nicolau).

- The DGOTH serves on the jury for public tenders to produce strategic tourism development strategic plans for Boa Vista and Maio, as well as the Integrated Tourism Development Zones (ZDTIs) of Chaves, Morro de Areia and Santa Mónica, and the Tourism Management Plan (POT) of the north and south of Vila do Maio (Boa Vista and Maio Islands Tourism Development Corporation - SDTIBM).

The program of complementary activities includes:

- Support for the preparation of territorial management master plans (PMOTs) and other plans by the DGOTH, in conjunction with the Association of Municipalities of Santiago;

- Preparation of land management plans and urban development planning; 
- Vocational training; and

- Refurbishment and modernization of the National Geodesic Network; and creation of a Territorial Information System.

Refurbishment and modernization of the National Geodesic Network is showing the following results:

- Construction of geodesic frameworks: in Brava, 11 nodes were refurbished, including those of Monte Gratão and Monte Gâmbia;

- Maintenance and identification of geodesic frameworks: in Fogo, 15 nodes were refurbished, including that of Monte Grande in Mosteiros, which the CMM team was responsible for completing; and in Santiago, the rehabilitation of frameworks was partially implemented and refurbishment took place in São Nicolau and Sal.

The greater density of the geodesic network in the main urban centers makes it possible for topographical work to be done in terms of cadastre, sanitation, and the road and port infrastructure to be linked to the National Geodesic Network, thereby making it possible to implement the geographic information system that is planned for national territory.

\subsubsection{Water Resource Management - Water and Sanitation}

\section{Strategic objectives:}

- Expansion and modernization of basic sanitation infrastructures, specifically in the areas of collection and treatment of effluents, collection and treatment of solid wastes, and their recycling.

- Establishment of new partnerships to create modern waste treatment and management units, particularly in urban centers, to improve the effectiveness of the system for collection and accommodation or treatment of solid waste nationally and locally.

- Better access for population groups to water and sanitation services, by strengthening and modernizing drinking water distribution infrastructures, wastewater collection and promotion of household water and sewerage connections.

- Incentives for investing in modern wastewater treatment and recycling systems, in the framework of integrated management of water resources and an increase in water availability. 
The medium-term objective is to improve access for families to a public supply system by taking policy steps to expand the public network to reach poor neighborhoods.

- An integrated plan of action on water resource management was prepared, which forms a national strategy for the sector in 2009. The plan of action is being analyzed by the National Water Council (CNAG) for subsequent approval. It makes clear that water availability indicators predict major scarcity of water per capita in the future, under all of the scenarios analyzed (normal rainfall or drought). The warning says that scarcity is well below the $1,000 \mathrm{~m}^{3}$ per year per inhabitant recommended by international standards. The quality of water particularly for public supply is also a key concern of integrated management.

- At the global level, efforts are being made to resolve disparities between the islands, between concelhos, and between rural and urban zones, to pool the efforts of the various management institutions and make up for the lack of leadership coordination particularly in the sanitation area. The current situation makes it difficult to assign responsibilities in some cases for the execution, management, and maintenance of water and sewerage networks; and it also hinders support and evaluation, and could interfere with the formation of policies for the subsector.

- On the supply side, the proportion of family connections to the public piped drinking water network, is expected to increase to 51 percent, from the 49.5 percent achieved in 2008, the benchmark year, in the concelhos of Praia, S. Vicente, Boavista and Sal.

- The volume of water in $\mathrm{m}^{3}$ is another performance indicator for the sector, but this target was not quantified for 2009 , and there is no base line for 2008 . Nonetheless, about 3.3 million $\mathrm{m}^{3}$ was used mainly for irrigation purposes.

- The wide variety of institutions operating the drinking water supply market, following the entry of public and private firms, led to the establishment of the Economic Regulation Agency (ARE) to regulate and control the provision of services, set fees, and inspect quality.

- The production of water by Electra, and its distribution of the islands of São Vicente, Sal, Boavista and in the concelho of Praia report an average coverage rate of 56 percent. At the national level, the percentage of families connected to the public network has a baseline of 46.9 percent.

In the water and sanitation infrastructure area, the following activities took place in 2009:

- Continuation of actions to capture surface run-off water for irrigation and supply of communities through boreholes and cisterns. 
- Feasibility study concluded for the water and sanitation project of the city of Assomada in Santa Catarina;

- Extension of the water supply and wastewater drainage system and collection of solid wastes in Mindelo, currently ongoing;

- Integrated solid waste management project in Santiago: approved by the municipalities of Santiago; municipal regulations on solid waste, hygiene, and urban cleaning were published; and the Santiago Intermunicipal Solid Waste Corporation was created;

- Studies are underway on the production of desalinated water in Calheta. This should be completed in the first quarter of 2010 ;

- Works for the production of desalinated water in Pedra Badejo were completed in May 2009.

Reservoirs

- The process of preparing the draft project, and preparing the terms of reference (caderno de encargos) and launch of the tender to recruit firms to construct three reservoirs in Santiago has begun.

In the wastewater sector, the medium-term objective for treatment is to improve families' access to a public sewerage network.

- For 2009, the proportion of families connected to the public sewerage system in the city of Praia should rise to 19 percent from 18 percent in 2008.

- Urban Mindelo is well served in terms of major sanitation equipment. It sewerage network benefits 56 percent of the population, and wastewaters are treated in the wastewater treatment station (WWTS) of Ribeira de Vinha and then recycled into irrigated agriculture.

- Tarrafal de Santiago has a sewerage network but households have not been connected and the small WWTS is nonoperational.

- Santa Cruz de Santiago, Pedra Badejo and Santa Maria recently built a wastewater treatment station.

- WWTSs are currently in the projection phase in the municipalities of Santa Catarina and Porto Novo. 
Wastewater drainage works have begun in Calheta and Mindelo, and storage and drainage of wastewater in the city of Praia.

The situation in terms of evacuation of excrement, drainage, and wastewater treatment remains precarious.

- The septic tank is the system most commonly used to evacuate wastewaters in Cape Verde.

- In the rural area, most of the population do not have evacuation systems

- The public toilets that exist in the various centers are little used by the population.

- The introduction of dry ventilated latrines in the rural area has not produced promising results, their viability is doubtful, and they are of limited impact. There seem to be cultural barriers that need to be overcome.

The next stage: The challenge for the sector is to serve poor population groups located in the outskirts of the main towns and/or scattered in rural areas. The challenge has economic and financial, technological, and managerial dimensions, and it needs to be addressed in the framework of broader integrating policies to reduce social exclusion, which include access to social housing, health, education, employment ... and better environmental quality.

Attempts to calculate the costs of attaining the Millennium Development Goals (MDGs), particularly in relation to water and sanitation, have failed. This would have made it possible to more realistically determine the sector's investment needs.

\subsubsection{Energy}

\section{Strategic orientations:}

- Increased competition and better regulation and supervision of the sector;

- Expansion of production capacity

- Greater penetration of renewable energies

- Implementation of energy conservation and efficiency measures

- Institutional capacity strengthening

- Investment in innovation and the adoption of more efficient technologies 
- Increase in electricity coverage to 100 percent

- Increase in the penetration of renewable energy sources

The national electricity production and distribution company is a key element in the sector's investment policy. Electra is going through a worrying situation both for the government and for donors. Its liquidity shortage means the government is taking responsibility for most of the investments. Resolution of its financial and organizational situation is crucial, and could be addressed by the National Energy Strategy.

The sector matrix highlights improvements in energy production and distribution, infrastructures, leading to a rising coverage rate compared the baseline set for 2007 , including:

- Average national coverage of 90 percent in 2009, which was not achieved. More recent data from Electra indicate an 87 percent coverage rate for the period 20002009 , in terms of the coverage of domestic customers or the number of families.

Nonetheless, the islands of São Vicente, São Nicolau, Boavista, Sal and Brava had coverage rates of 100 percent in 2009. Projections for 2011 and 2012 show that the island of Maio and the concelhos of Praia, São Domingos and Santa Catarina should attain 100 percent coverage in 2011.

- The production of renewable energy (wind and solar) and its incorporation into the distribution network, remains minimal at 3 percent; and there is a lot of room for substantial progress in the near future, when the target is to reach 25 percent as a result of projects in the pipeline.

\subsection{Pillar V - Social Cohesion}

Social cohesion is an essential principle for building a more integrating and balanced society, and for mitigating poverty. Social country's inequalities affect children, the elderly, the disabled, and women heads of family and young people the most.

\subsubsection{Poverty}

Cape Verde's Human Poverty Index (HPI) was calculated at 15.8 percent in 2006 by the National Institute of Statistics.

Implementation of the different social policies through various programs and projects to improve access to core social services, include vulnerable groups, and promote local community development initiatives have had major success. The National Poverty Reduction 
Program (PNLP) has been recommending actions mainly targeting poverty reduction, increasing solidarity, and equal opportunities.

The priority intervention areas are:

- Income-generating activities;

- Water supply and sanitation;

- Education and vocational training;

- Institutional support; and

- Low-income housing.

Actions target low-income women, particularly those who are heads of family, as well as unemployed youth and families living below the poverty line.

The next stage calls for an innovative approach to poverty reduction, based on coresponsibility by involving everyone in poverty reduction and social cohesion.

- The new approach of the PNLP will prioritize actions aimed at social integration/development of the employability of individuals and families, and resultsdriven management in the poorest communities.

\subsubsection{Work/Social Protection}

Strategic orientations:

- Redefinition of the public institutional framework for coordination and implementation of social protection policies;

- Deepening of the process of decentralizing social protection policies;

- Definition of a regulatory and institutional framework of public-private partnership in the social protection area;

- Consolidation of the process of legal and institutional reform on childhood and adolescence.

The following studies were undertaken in relation to planning: "Trabalho Infantil" [Child labor] and "Plano de Prevenção e Combate ao Trabalho Infantil" [Plan to prevent and combat child labor], "VuInerabilidade das crianças face à graduação de Cabo Verde a país 
de rendimento médio" [Vulnerability of children as Cape Verde becomes a middle-income country], and "Estratégia de Desenvo/vimento de microempresas rurais" [Development strategy for rural microenterprises].

In terms of prevention, publications include the "Guias Educativos sobre Trabalho Infantil" [Educational guidelines on child labor] and "Abuso e Exploração Sexual de Crianças" [Sexual abuse and exploitation of children].

In terms of improving working conditions and improving social dialogue, actions in 2009 targeted institutional and individual strengthening and capacity building for services to promote better working conditions.

Capacity-building prioritized the prevention of workplace hazards. In addition, 869 inspection visits were made, resulting in the apprehension of 600 illegal fixed-term contracts.

Prevention actions prioritized the mediation/conciliation and settlement of disputes, the promotion of social dialogue, and decent jobs. Several sessions were also held to disseminate labor legislation and counseling.

The Social Concertation Council was active, including initiatives for a viability study to implement the minimum wage.

Partnerships included:

- The agreement with the adult education and training department (DGAEA) to encourage people to return to education;

- The Protocol signed with the PNLP and central and local public authorities and with CITI-Habitat for the refurbishment of housing, vocational training and promotion of income-generating activities throughout the country.

In relation to access to social protection services for social and professional groups, the social security regime for employed workers guaranteed a wide range of coverage with:

- The inclusion of 16,093 users from central government and 1,323 from the local public administration regime. Currently, 24 percent of the active resident population are covered by this regime, which guarantees coverage in the event of economic and social needs resulting from illness, maternity, disability, the provision of medical assistance. It also grants subsidies to families with children and elderly dependents.

In the contributory social protection regime, there were substantial increases in the number of:

- Contributors ... from 3852 to 4045 ;

- Persons insured ... from 61,751 to 69,216 ; and 
- Beneficiaries ... from 141,548 to 146,000 .

In the noncontributory social protection regime, the National Social Pensions Center (CNPS) was created.

The center provides integrated management of the social pensions financed by the State and by the Mutualista Fund. ${ }^{10}$ The CNPS has developed an operational plan to implement the social protection strategy, and works with municipal councils, municipalized social promotion services, and civil society organizations to identify individuals living in poverty, and process applications for the social pension, etc.

The number of social pension recipients has grown to 22,946 (the vast majority of whom are elderly, chronically ill, persons with disabilities, and former FAIMO workers), which virtually satisfies the target of 23,000 set for 2009 .

With regard to the social pension:

- In 2009, a total of 1,922 individuals were entitled to the social pension (basic pension: 1508; social disability pension: 241 ; and social survivor pension: 32 ). The growth rate of the population covered is 1.3 percent, well below the rate in previous years, which may indicate universal coverage of the target group.

- The value of the social pension in the noncontributory regime is CVE 4,500 (November 2009), which is close to the target set by the government of CVE 5,000 before 2011, paid through post offices.

The information system that manages the social pension has proposals for redesigning its database to incorporate variables making it possible to better identify the pensioner profile, together with connection with databases of the National Social Security Institute (INPS) and the Directorate General of Social Security Contributions and Taxes.

In terms of legislation, laws were published on own-account workers, domestic service workers, and a law on workplace accidents and professional illnesses, together with regulatory laws on CVI, patient evacuation and protection during periods of illness.

In 2009, actions in the area of Protection of the Rights of the Child and Adolescent, targeted promotion and dissemination, through solidarity and awareness-raising campaigns, and education on the rights of the child, protection, support, partnership, institutional development, social reintegration and poverty reduction. The country ratified the Hague

10 This fund was regulated in November 2009 and will be managed by a financial institution to be contracted for this purpose. The fund pays social pension beneficiaries for the provision of preventive, curative, and rehabilitation health care, subsidies for medicines, and a funeral subsidy to a family member or legal inheritor of a deceased pensioner. 
Convention (on international adoption), produced a second version of the Child and Adolescent Charter (ECA), and published the Convention of the Rights of the Child. The charter of the Institute of Childhood and Adolescents is being reviewed.

In relation to support, needy students, families, and the sick (evacuated) received specific help, as well as social promotion services to cope with the disasters caused by the rains.

\subsubsection{Social housing}

\section{Strategic orientations:}

- Creation of humanized urban spaces with special priority for the organization and upgrading of neighborhoods

- Targeting of urban development policy on issues of environmental sustainability, which is a decisive factor for spatial, social, and functional integration of the territory

- Land management as a process of change, social cohesion, and deepening of mechanisms for public participation in urban development quality

- Response to new demands in various areas such as free spaces, culture, recreation and leisure

- Recovery and upgrading, particularly in degraded housing areas in neighborhoods on the outskirts of cities.

The medium-term objective for low-income housing is to improve housing conditions for the poorest citizens in particular.

There is a housing deficit of 82,000 homes, which affects all levels of income but has a major impact on lower-income population segments who are excluded from the formal housing market.

In the search for a structuring solution to this challenge, the government's social housing policy is gaining priority on the public agenda for the next few years. Consequently:

- Several social housing programs are currently executing, which address the socioeconomic inclusion of families, the fight against poverty, environmental impacts, development of partnerships, etc.

- The legislative basis of social housing contains a package of proposed laws and decrees currently being processed. 
- The government created the Social Housing Fund (FHIS) which centralizes and manages resources to execute housing policies targeting deprived families and/or population groups with specific support needs (e.g. young people, the lower middle class, women heads of family).

In 2009, the government prepared and approved a strategic plan for the sector, entitled "Casa Para Todos" [A house for all], which includes the following programs:

(i) Habitar Cabo Verde - which aims to reduce the housing deficit, both qualitatively and quantitatively, by 2013 , building about 8,000 homes;

(ii) Programitas - which aims to build about 1,000 new housing units in rural areas with the aim of reducing the quantitative deficit in the rural sector.

(iii) Reabilitar - which aims to improve the quality of life of people living in informal neighborhoods, through rehabilitation and infrastructure programs in residential areas.

"Operação Esperança” [Operation Hope] targeted on improving living conditions among the least privileged groups.

- A partnership protocol was signed with the PNLP, to rehabilitate housing and promote income-generating activities throughout the country. Unfortunately, no data are available on the actions undertaken.

- Support was provided for social promotion services to assist families in coping with the disasters caused by the rains, particularly in São Nicolau.

Next stage:

To meet the challenges of social cohesion, the government aims to implement a new generation of active social policies and expand partnerships nationally and internationally. It also intends to expand the coverage of social protection to encompass informal workers, rural workers, and fishery workers who are currently outside the system. In addition, alternative construction methods are being tested and introduced. A holistic approach and consistent plan of action are needed on this issue. 


\section{Crosscutting issues (gender, environment, research)}

\section{1 $\quad$ Gender}

\section{Strategic orientations:}

- Effectively mainstream gender in sector policies and in programs and projects

- Create and implement affirmative action mechanisms to increase women's participation in the legislature, judiciary, and local authorities

- Enforce the juridical-legal provisions that are currently in force, particularly their regulations, to ensure the real benefit of the underlying protection provisions;

- Adopt mechanisms that promote equal opportunities and greater participation by women in economic activities;

- Strengthen partnerships with civil society organizations that promote citizenship and the family, defense of women's rights, and promotion of community development and poverty reduction.

In 2009, actions to create conditions for the effective exercise of citizenship were strengthened. These also favor gradual elimination of situations of violence and discrimination, rights protection and, in particular, in terms of women's political and economic participation, through the implementation of the National Plan on Gender Equality and Equity and the Plan to Combat Gender Violence.

Thanks to the existence of a juridical-legal framework favorable to gender equality, significant progress has been made in recent years such as:

- (i) A literacy index of 73 percent for women and 87 percent for men in 2007; (ii) the enrolment rate in both basic and secondary education is higher for a girls than for boys.

Consequently, implementation of the "Education for all" public policy has resulted in a clear democratization of access and has led to gender equity in education.

In the health sector, the number of adolescent mothers remains high, reflecting a combination of educational and economic fragilities that lead to a situation of family and social fragility. The prevalence of HIV/AIDS has been declining, and is currently 0.8 (IDSR II, INE). The masculinity ratio of HIV/AIDS prevalence is 1.13 , thus indicating that men are more susceptible than women. 
In relation to gender violence, and as a result of work done by various institutions and social communication, women are now more aware of their rights, which is expressed in the social desire to speak out on the issue.

The proportion of women members of parliament rose from 11 percent to 21 percent between 2003 and 2008. In terms of top ministerial posts, this is the second government in the world with the same number of women and men ministers.

Our media still does not effectively promote good practices in terms of gender relations. Messages transmitted in the media continue to project an image of women that has little to do with the female condition, or insistently projects them as victims.

The Gender-Adjusted Development Index is 0.749 (INE, 2006). The Legal Advice Bureaus and Citizen Bureaus give special attention to domestic violence issues and reducing inequalities in access to services.

\section{$4.2 \quad \underline{\text { Environment }}$}

\section{Strategic orientations:}

- Promotion of development with environmental quality

- Protection and integrated management of natural resources that are essential for economic development

- Poverty reduction

- Adaptation of modes of production and consumption

The medium-term objective for environmental management is to satisfactorily implement the government's environmental policy. This objective entails balanced management of water resources and biodiversity. Execution of the Environmental Policy in 2009 included the implementation of municipal, sector, and central environmental plans.

- The annual report on the execution of environmental policy for 2009 is the indicator of the results achieved. It was approved by the National Environment Council (CAN), as shown by the minutes of the meeting. Consequently, the degree of execution is 100 percent.

- In 2009, the government obtained financing for a review of the National Action Plan on the Environment (PANA II). The review process will only end in 2010.

An environmental quality monitoring system (Sistema de Seguimento de Qualidade Ambiental - SSQA) was developed in 2009. 
- The first report on the state of environmental quality was completed. This tracks 31 of the 76 indicators proposed, and made it possible to evaluate the overall state of the environment in Cape Verde.

The SSQA, in conjunction with the development of a system for financial control of investments in the environment (to be completed in 2010), will make it possible to monitor and evaluate the overall state of the environment in the country, and track its evolution more rapidly and securely.

- A proposal for a matrix to evaluate the sector performance was finalized and accepted by all participants, in the framework of budgetary support for the period 2009-2011. The sector matrix makes a change in a number of indicators, e.g. execution indicators relating to protected areas (a total of 47 land and marine areas) and species management plans which were reduced and better adjusted to reality.

- Reformulation of the Ecological Levy (taxa ecológica) to conform to WTO regulations: the impasse in Parliament over its approval relates to the distribution of the proceeds of the levy between the Environmental Fund and Municipal Environmental Programs.

The intention is that the proceeds of the ecological levy will become an important tool for financing environmental issues.

According to data from the 2007 QUIBB:

- The proportion of the population that uses a drinking water source is 89.5 percent in $2007,98.6$ percent in the urban area and 75.8 percent in rural zones.

- In 2007, just 40.8 percent of Cape Verdean families reported evacuating wastewater through a septic tank and a sewerage system.

The situation clearly improved between 2007 and 2009, when more than 1,365 household water connections were made, as well as 656 connections to sewerage networks.

- In the area of wastewater treatment, in late 2009, apart from the launch of WWTSs in Mindelo and Praia, WWTSs were completed in Tarrafal and Santa Cruz in Santiago and Santa Maria on Sal. The Tarrafal WWTS will benefit 250 families, and the second 20,000 people. The Mindelo WWTS was expanded, which will facilitate an increase in the volume of wastewater treated in 2013.

- The positive results obtained from construction of the Polião reservoir in terms of the capture and distribution of water to irrigate over 60 ha of land, and the incentive for agricultural and rural development, led to the decision to construct another 11 
reservoirs (five in Santiago, three in Santo Antão, one in São Nicolau, one in Maio and one in Boa Vista.

- It is estimated that 652,700 ha of agricultural land nationwide is being operated with the droplet irrigation system.

In terms of improving hygiene conditions for a healthy environment, solid waste collection services cover about 85 percent of the country's municipalities. Nonetheless, there is still no separation and treatment.

Seven confined waste disposal sites (São Vicente, Sal, Tarrafal and Ribeira Brava

- in SN, Santa Catarina and São Miguel in ST and Porto Novo) operate in the country, along with five improvised municipal waste tips (Praia, Paúl, Tarrafal de ST, São Filipe and Maio), where nonbiodegradable solid wastes are deposited.

- The sanitary landfill of Sal is currently being implemented and studies and projects are being conducted for the controlled landfill on Santo Antão. On Fogo an incineration unit has been set up in the municipality of São Filipe.

As the illegal extraction of inert material from the ocean beaches remains a serious environmental problem, the percentage of locally sourced sand consumed was chosen as one of the performance indicators for improving environmental governance.

- To combat illegal extraction, national police officers involved in inspection actions received specific training to improve their performance, and their number was increased in all concelhos.

- Illegal sand consumption has been declining over the last two years. In 2009, 83 percent of sand consumption was legal, thanks to the functioning of: (i) quarries producing sand from stone; (ii) the granting of facilities for sand imports; and (iii) the requirement of financiers of large infrastructure works to use sand obtained legally.

This performance is better than the target of 65 percent of sand consumed with legal origin established for 2009.

- Little progress has been made in developing the plan of action for the extraction of sand, except for a survey of the potential for producing inert materials on the different islands, which is essential for preparing the study on the production of inert material and production of the plan.

In 2009, in terms of biodiversity management, actions included:

- Publication in the Official Gazette (B.O.) of management plans for the Serra Malagueta and Monte Gordo natural parks. The management plan for the Fogo 
natural park was prepared in 2009 but not approved. The management plans for the protected marine areas of Baía da Murdeira and Ilha de Santa Luzia and neighboring islets (ilhéus) are in the final formulation phase.

The following were approved for conservation and preservation of species:

- The National Plan for Conservation of Marine Turtles, and execution thereof began; the National Plan for Bird Conservation was published in January 2009.

- Species inventories were carried out for angiosperm plants threatened with extinction on Santiago, Fogo, São Nicolau, Santo Antão and São Vicente; and a bird species inventory was conducted in Santiago, Boavista, Fogo and Ilhéu Raso.

- 1,402 saplings from three native endemic plant species threatened with extinction were reproduced in nurseries, to be used in the recovery of high altitude habitats; 3,000 endemic medicinal plants threatened with extinction were reproduced in nurseries.

- The germoplasm bank was maintained and conserved with seeds from 25 plant species.

The inventory of the use of endemic plant species shows that they are used mostly as forage (52 percent in Santiago, 29.7 percent in São Nicolau, and 37 percent on Fogo).

- Monitoring and data updating was undertaken on the population of terrestrial fauna species threatened with extinction, namely: Cane Warbler (Tchota de Cana), Purple Heron, Bar-tailed Lark (Calhandra), and Cape Verde Shearwater (Cagarra).

- Nests, adults, and young of the purple heron were monitored in Santiago, and also for Fea's Petrel (Gongon) on the island of Fogo.

- 103 individuals of the Bar-tailed Lark species were counted on Ilhéu Raso, and their nests were georeferenced; in the case of the Cape Verde Shearwater, 8,000 nests were counted on Ilhéu Raso, resulting from an intensive awareness raising and supervision campaign on the islet in October 2008.

- In addition, five Osprey (Guincho) nests were monitored and inventoried, along with 120 pairs of albatross and 30 individuals of Bulwer's Petrel (João Preto) on Ilhéu Raso.

In the area of marine resources, promotion actions targeted: 
- Sustainable fishing, through implementation of the Fishery Resources Management Plan and its recommendations, specifically the preparation of studies on the meditation of management measures.

- Conservation and protection of marine turtles has been successful thanks to the protection activities undertaken in all coastal municipalities, which enabled greater vigilance and supervision, thereby allowing an increase percentage of turtles escaping after laying eggs and fewer captures.

Nonetheless, the extraction of sand, night-time lighting of beaches and occupation of the coastal area pose the greatest threats to marine turtles.

Inspection actions included:

- Larger number of inspection actions; environmental audits on firms, with three cases being brought for violations of projects requiring the presentation of environmental impact assessments, that did not comply with the law;

As regards the indicator on the proportion of projects approved according to the environmental impact assessment (EIA):

- 71 environmental impact assessments were evaluated, of which 36 were approved (50 percent), 26 were exempted from the EIA process, and nine were rejected for failing to comply with current legislation.

Environmental projects are executed on a decentralized basis through municipal environmental plans. In most cases, implementation is financed with funds made available from the municipalities through the program contracts signed between the government and the municipalities

- The Autonomous Municipal Development Fund is legal instrument created to finance the implementation of municipal investment programs and projects that are not yet operational.

- In February 2009, program contracts began to be signed with municipalities to implement environmental projects that had previously been chosen by the PANA II monitoring committee (CGS-PANA II).

\subsection{Investigation/research for development}

\section{Strategic orientation:}

- Create conditions for development of endogenous capacity for research and innovation 
As part of its modernization, new statutes were approved for the INE, the Law on Statistics was published in the B.O., and QUIBB 2007 data were put on Statline.

The results or effects of research done in the areas of fisheries, agriculture, education, culture, housing infrastructure, etc., will be used as inputs for the various sector development policies and strategies.

Agricultural research undertaken by the National Institute of Agricultural Research and Development (INIDA) concerns the selection, multiplication, and protection of plant species, control of animal health, and support for fishery development.

- In 2009, INIDA continued trials for the selection and introduction of species and varieties adapted to Cape Verdean conditions; it also monitored and tracked pests and diseases affecting the main irrigated crops and animals, and it monitored their impact.

- In the biodiversity sphere, in 2008 and 2009 it continued to monitor the fauna and flora of the islands of São Nicolau, Santiago, and Santo Antão.

- In terms of rural development, the activities undertaken form part of the Strategic Plan for Agriculture for 2014, and included modernization through the introduction and use of new techniques, technologies, and methods of production and protection (greenhouses, species and varieties adapted to edafo-climatic conditions) and the upgrading of agricultural products.

The National Institute of Fishery Development (INDP) has conducted aquaculture management research and feasibility studies on alternatives to small-scale fishing in the close season.

Various activities were undertaken to reduce the inherent risks of natural or human-made disasters:

- Procurement of equipment (Cluster and PCS) for the recovery and adaptation of the global climate monitoring system;

- Installation of the INTRNET network to make operational models for the production of meteorological forecasting products and dissemination of meteorological products to protect lives and property.

- The maritime meteorology project is underway;

- Installation of 6 automatic weather stations (AWS) and one AWS to guarantee the functioning and use of classic and automatic meteorological stations and altitude observations on all islands; 
- Installation of a new radio/sonar station; and

- Configuration of the data transmission network for geophysical monitoring.

In the culture sphere, research activities were undertaken leading to the publication of various cultural works.

In the construction area, the initiative Prémio Incentivos à Investigação $e$ Inovação em Tipologias e Tecnologias de Construção [Award incentives for research and innovation in construction typologies and technologies] was introduced at a time of major constraints in the housing and construction sector, particularly in relation to costs. This award provides an opportunity and incentive to undertake research and develop new typologies and methodologies of construction that will reduce costs and improve building quality, with a view to improving access to housing.

\section{Monitoring and evaluation mechanisms}

A system is being set up that is capable of providing real-time data for the annual status report on PRGS execution, or for some other time period to be established.

- Development of the monitoring and evaluation system has been based mainly on the principles of simplicity and facility of use and affordable costs.

The institutional framework, a key condition for system development, has been set up.

- It has a central office in the National Planning Department of the Ministry of Finance (with minimum staffing) and in most of the ministries/sectors (Directorate -General of Planning, Budget, and Management - DGPOG); and it has agents in the concelhos and islands of the country. The S\&A has its information system in the INE and SIGOF.

- In 2009, access for sector bodies to information on budgetary execution was expanded and deconcentrated, particularly regarding authorization and settlement in SIGOF. This situation makes it possible to automatically record and store execution (operational) data in the SIGOF databases.

Apart from sectors/ministries, there several other institutions are currently in the SIGOF, such as the Office of the President of the Republic, the Supreme Court, the Auditor General Department, the National Electoral Commission, and the Office of the Prime Minister.

- For 2010, short specific training actions are programmed to implement the information system (crucial for the S\&A mechanism), targeting ownership by the 
national structures, particularly middle management and technical staff responsible for monitoring, which should begin in 2010 .

6. Conclusion

Overall progress in implementing PGRS in 2009 can be considered positive, and the results achieved are testimony to a collective effort to fulfill the objectives set in terms of attaining the defined targets.

The various sectors made positive contributions during the preparation, monitoring of the PGRS, and the mission itself. Nonetheless, there was some delay in submitting data and a failure to meet deadlines. These situations impose constraints on the normal development of the work. We reiterate here that PGRS data needs to be harmonized with those of the GAO.

We evaluate the progress made as positive and consider that, overall, the sectors have fulfilled their objectives and implementation of the GPRSP, resulting in effective implementation of the poverty reduction and growth strategy in Cape Verde.

7. Update of the General Joint Matrix for Budget Support (in Annex). 
Annex - General Joint Matrix for Budget Support to the Government of Cape Verde

\begin{tabular}{|c|c|c|c|c|c|c|c|}
\hline \multirow[b]{2}{*}{ Topics } & \multirow[b]{2}{*}{ No. } & \multirow[b]{2}{*}{ Objectives } & \multicolumn{4}{|c|}{ Evaluation } & \multirow[b]{2}{*}{ Monitoring } \\
\hline & & & $\begin{array}{c}2008 \\
\text { (Base) }\end{array}$ & 2009 & 2010 & 2011 & \\
\hline Macroeconomy & 1 & Stability & + & + & & & MFAP \\
\hline Poverty reduction & 2 & Implementation of PRGS I / PRGS & + & + & & & MFAP \\
\hline Public finance management & 3 & Progress in implementing reforms & + & + & & & MFAP \\
\hline
\end{tabular}




\begin{tabular}{|c|c|c|c|c|c|c|c|c|c|c|}
\hline \multirow{2}{*}{$\begin{array}{l}\text { Medium-term } \\
\text { objectives }\end{array}$} & \multirow[b]{2}{*}{ No. } & \multicolumn{3}{|c|}{ Policy measures and actions } & \multirow[b]{2}{*}{ Indicators } & \multirow{2}{*}{$\begin{array}{l}\text { Base } \\
2008\end{array}$} & \multicolumn{3}{|c|}{ Reference points } & \multirow{2}{*}{$\begin{array}{l}\text { Monitoring } \\
\text { (entity } \\
\text { responsible) }\end{array}$} \\
\hline & & 2009 & 2010 & 2011 & & & 2009 & $\begin{array}{l}2009 \\
\text { result }\end{array}$ & $\begin{array}{l}\text { Verificati } \\
\text { on doc. }\end{array}$ & \\
\hline \multicolumn{11}{|c|}{ Pillar 1-Good Governance } \\
\hline \multicolumn{11}{|l|}{ Macroeconomy: } \\
\hline \multirow[b]{2}{*}{$\begin{array}{l}\text { Reduce and } \\
\text { control liabilities } \\
\text { including } \\
\text { contingencies }\end{array}$} & & $\begin{array}{l}\text { Implementation } \\
\text { of the plan for } \\
\text { settlement of } \\
\text { overdue loans } \\
\text { (Completed) }\end{array}$ & $\begin{array}{l}\text { Conclusion of } \\
\text { implementation of the } \\
\text { plan for settlement of } \\
\text { overdue loans }\end{array}$ & & $\begin{array}{l}\text { Amount } \\
\text { outstanding on } \\
\text { overdue } \\
\text { government loans } \\
(\%)\end{array}$ & 60 & 38 & 31 & DGT report & \\
\hline & & $\begin{array}{l}\text { Preparation of a } \\
\text { plan of action } \\
\text { with a deadline } \\
\text { for the } \\
\text { settlement of } \\
\text { Electra debts } \\
\text { with suppliers } \\
\text { within a } \\
\text { maximum of } \\
\text { four years } \\
\text { (Completed) }\end{array}$ & $\begin{array}{l}\text { Implementation of the } \\
\text { plan for the settlement } \\
\text { of Electra's overdue } \\
\text { loans with suppliers }\end{array}$ & $\begin{array}{l}\text { Implementation of } \\
\text { the plan for the } \\
\text { settlement of } \\
\text { Electra's overdue } \\
\text { loans with } \\
\text { suppliers }\end{array}$ & $\begin{array}{l}\text { Amount } \\
\text { outstanding on } \\
\text { overdue Electra } \\
\text { debts with } \\
\text { suppliers }(\%)\end{array}$ & 100 & 100 & $\begin{array}{l}\text { (To be } \\
\text { confirmed } \\
\text { with } \\
\text { Electra) }\end{array}$ & & MFAP \\
\hline \multicolumn{11}{|c|}{ Budgetary planning and financing: } \\
\hline $\begin{array}{l}\text { Use medium- } \\
\text { term fiscal } \\
\text { framework } \\
\text { (MTFF) }\end{array}$ & & $\begin{array}{l}\text { Preparation of } \\
2010-2012 \\
\text { framework } \\
\text { (Completed) }\end{array}$ & $\begin{array}{l}\text { Preparation of } 2011 \text { - } \\
2013 \text { framework }\end{array}$ & $\begin{array}{l}\text { Preparation of } \\
2012-2014 \\
\text { framework }\end{array}$ & $\begin{array}{l}\text { MTFF } \\
\text { presented to } \\
\text { Parliament as part } \\
\text { of the Budget Law }\end{array}$ & Yes & Yes & Prepared & & $\begin{array}{l}\text { MFAP/ Strategic } \\
\text { Studies } \\
\text { Department }\end{array}$ \\
\hline \multirow[t]{2}{*}{$\begin{array}{l}\text { Expand the use } \\
\text { of the MTFF }\end{array}$} & & \multirow{2}{*}{$\begin{array}{l}4 \text { ministries } \\
\text { prepare MTFF } \\
\text { for } 2010 / 2012 \\
\text { (Completed) }\end{array}$} & \multirow[t]{2}{*}{$\begin{array}{l}8 \text { ministries prepare } \\
\text { MTFF for } 2011 / 2013\end{array}$} & \multirow{2}{*}{$\begin{array}{l}\text { All ministries (15) } \\
\text { prepare MTFF } \\
\text { 2012-2014 }\end{array}$} & $\begin{array}{l}\text { Specialized MTFF } \\
\text { units created }\end{array}$ & 3 & $>5$ & $5 \mathrm{OK}$ & $\begin{array}{l}\text { Orders } \\
\text { from } \\
\text { ministers }\end{array}$ & \multirow{2}{*}{$\begin{array}{l}\text { General Budget } \\
\text { Directorate } \\
\text { MFAP }\end{array}$} \\
\hline & & & & & $\begin{array}{l}\text { Number of } \\
\text { sectors with } \\
\text { MTFF }\end{array}$ & 2 & 4 & 12 & $\begin{array}{l}\text { Existing } \\
\text { docs. }\end{array}$ & \\
\hline \multicolumn{11}{|c|}{ Budgetary execution: } \\
\hline $\begin{array}{l}\text { Expand use of } \\
\text { the integrated } \\
\text { system }\end{array}$ & & $\begin{array}{l}\text { Increase } \\
\text { budgetary } \\
\text { units' access to } \\
\text { SIGOF }\end{array}$ & $\begin{array}{l}\text { Adoption of } \\
\text { cumulative value: } \\
\text { State assets partly } \\
\text { recorded cumulatively } \\
\text { in State accounts. }\end{array}$ & & $\begin{array}{l}\% \text { of government } \\
\text { budget units with } \\
\text { access to SIGOF }\end{array}$ & $80 \%$ & $90 \%$ & 91.2 & $\begin{array}{l}\text { DNOCP } \\
\text { report }\end{array}$ & MFAP \\
\hline
\end{tabular}




\begin{tabular}{|c|c|c|c|c|c|c|c|c|c|}
\hline \multicolumn{10}{|c|}{ Internal controls: } \\
\hline \multirow{3}{*}{$\begin{array}{l}\text { Increase IGF } \\
\text { capacity to } \\
\text { conduct more } \\
\text { controls }\end{array}$} & & \multirow{3}{*}{$\begin{array}{l}\text { Recruit or bring } \\
\text { trained staff back to } \\
\text { the IGF }\end{array}$} & & $\begin{array}{l}\text { Number of } \\
\text { inspections } \\
\text { performed by the } \\
\text { IGF }\end{array}$ & & 39 & 64 & $\begin{array}{l}2009 \mathrm{IGF} \\
\text { report lacks } \\
\text { DG }\end{array}$ & \multirow{3}{*}{ IGF } \\
\hline & & & & $\begin{array}{l}\text { Number of } \\
\text { inspections in FSA } \\
\text { and municipalities }\end{array}$ & & 14 & 44 & $\begin{array}{l}2009 \mathrm{IGF} \\
\text { report }\end{array}$ & \\
\hline & & & & $\begin{array}{l}\text { Number of training } \\
\text { sessions }\end{array}$ & & 5 & 11 & $\begin{array}{l}2009 \text { IGF } \\
\text { report }\end{array}$ & \\
\hline \multicolumn{10}{|c|}{ External controls: } \\
\hline $\begin{array}{l}\text { Improve the } \\
\text { timeliness of } \\
\text { audits on } \\
\text { government } \\
\text { accounts by the } \\
\text { Auditor } \\
\text { General's Office }\end{array}$ & & $\begin{array}{l}\text { Increase the staffing } \\
\text { and budget assigned to } \\
\text { the Auditor General's } \\
\text { Office }\end{array}$ & & $\begin{array}{l}\text { Latest government } \\
\text { accounts verified }\end{array}$ & $\begin{array}{l}2005 \\
\text { government } \\
\text { accounts } \\
\text { verified }\end{array}$ & $\begin{array}{l}2006 \text { and } \\
2007 \\
\text { government } \\
\text { accounts } \\
\text { verified }\end{array}$ & $\begin{array}{l}\text { Governmen } \\
\mathrm{t} \text { accounts } \\
\text { prepared } \\
\text { and } 2006 / 7 \\
\text { verified }\end{array}$ & $\begin{array}{l}\text { Opinion on } \\
\text { general } \\
\text { government } \\
\text { account }\end{array}$ & $\begin{array}{l}\text { Auditor } \\
\text { General's Office }\end{array}$ \\
\hline \multicolumn{10}{|c|}{ National public procurement system: } \\
\hline \multirow{4}{*}{$\begin{array}{l}\text { Improve } \\
\text { transparency and } \\
\text { efficiency }\end{array}$} & $\begin{array}{l}\text { Publication of } \\
\text { new regulations } \\
\text { (Completed) }\end{array}$ & $\begin{array}{l}\text { Evaluate performance } \\
\text { of procurements for at } \\
\text { least three ministries } \\
\text { Finance, Health, and } \\
\text { Transport/Equipment }\end{array}$ & $\begin{array}{l}\text { Continue to } \\
\text { evaluate } \\
\text { performance for at } \\
\text { least five } \\
\text { ministries: } \\
\text { previous } 3+ \\
\text { Education and } 1 \text { to } \\
\text { be chosen }\end{array}$ & $\begin{array}{l}\% \text { non- } \\
\text { performance, } \\
\text { contracts awarded } \\
\text { directly }\end{array}$ & $\mathrm{n} / \mathrm{a}$ & $\mathrm{n} / \mathrm{a}$ & 10 & 0 & ARAP \\
\hline & \multirow{3}{*}{$\begin{array}{l}\text { ARAP and } \\
\text { UGAs } \\
\text { operational in } \\
\text { the respective } \\
\text { ministries, i.e. } \\
\text { staff appointed } \\
\text { and regulation } \\
\text { approved } \\
\text { (Completed) }\end{array}$} & $\begin{array}{l}\text { National standard } \\
\text { bidding } \\
\text { documents/market } \\
\text { consultation approved }\end{array}$ & $\begin{array}{l}\text { Deal with } \\
\text { complaints } \\
\text { transparently and } \\
\text { efficiently }\end{array}$ & $\begin{array}{l}\% \text { of complaints } \\
\text { dealt with in } \\
\text { accordance with } \\
\text { new regulations } \\
\text { and published }\end{array}$ & 0 & 0 & 50 & 100 & \multirow{3}{*}{ ARAP/UGA } \\
\hline & & $\begin{array}{l}\text { Develop, adopt, and } \\
\text { start implementation of } \\
\text { a national public } \\
\text { procurement training } \\
\text { strategy }\end{array}$ & \multirow{2}{*}{$\begin{array}{l}\text { Create the } \\
\text { integrated public } \\
\text { procurement } \\
\text { system MIS and } \\
\text { M\&A to evaluate } \\
\text { performance }\end{array}$} & \multirow{2}{*}{$\begin{array}{l}\text { Average time to } \\
\text { process } \\
\text { procurements } \\
\text { (months) }\end{array}$} & \multirow[t]{2}{*}{10} & \multirow[t]{2}{*}{10} & \multirow[t]{2}{*}{10} & \multirow[t]{2}{*}{$\begin{array}{l}\text { Activities } \\
\text { report } 2009\end{array}$} & \\
\hline & & $\begin{array}{l}\text { Public procurement } \\
\text { website operational } \\
\text { and publicly accessible }\end{array}$ & & & & & & & \\
\hline
\end{tabular}




\begin{tabular}{|c|c|c|c|c|c|c|c|c|c|}
\hline National monit & d evaluation s) & stem: & & & & & & & \\
\hline \multirow{3}{*}{$\begin{array}{l}\text { Make it } \\
\text { operational }\end{array}$} & $\begin{array}{l}\text { Conclusion of } \\
\text { the evaluation } \\
\text { of training } \\
\text { needs in M\&A } \\
\text { and results- } \\
\text { based } \\
\text { monitoring } \\
\text { (RBM) } \\
\text { (Completed) }\end{array}$ & $\begin{array}{l}\text { Implementation of the } \\
\text { training plan }\end{array}$ & $\begin{array}{l}\text { Implementation of } \\
\text { the training plan }\end{array}$ & $\begin{array}{l}\text { Training plan for } \\
\text { RBM and M\&A }\end{array}$ & 0 & & $\begin{array}{l}\text { Plan } \\
\text { approved }\end{array}$ & $\begin{array}{l}\text { Budget } \\
\text { program } \\
\text { exists }\end{array}$ & \multirow{3}{*}{$\begin{array}{c}\text { DGP } \\
\text { DGPOGs/GEPs } \\
\text { INE } \\
\text { NOSI }\end{array}$} \\
\hline & $\begin{array}{l}\text { Preparation of a } \\
\text { strategic plan } \\
\text { for M\&A and } \\
\text { RBM } \\
\text { (Partially } \\
\text { completed) }\end{array}$ & $\begin{array}{l}\text { Implementation of the } \\
\text { strategic plan }\end{array}$ & $\begin{array}{l}\text { Implementation of } \\
\text { the strategic plan }\end{array}$ & $\begin{array}{l}\text { No. of staff trained } \\
\text { in M\&A }\end{array}$ & 8 & 12 & 31 & $\begin{array}{l}\text { PASRP I } \\
\text { report third- } \\
\text { quarter }\end{array}$ & \\
\hline & $\begin{array}{l}\text { All output } \\
\text { indicators of } \\
\text { projects and } \\
\text { programs for } \\
2008 \text { integrated } \\
\text { into the } \\
\text { national M\&A } \\
\text { system } \\
\text { (Not done) }\end{array}$ & $\begin{array}{l}\text { All active project and } \\
\text { program output } \\
\text { indicators integrated } \\
\text { into the national M\&A } \\
\text { system. }\end{array}$ & $\begin{array}{l}\text { Output and } \\
\text { outcome indicators } \\
\text { of all active } \\
\text { projects and } \\
\text { programs } \\
\text { integrated into the } \\
\text { national M\&A } \\
\text { system }\end{array}$ & $\begin{array}{l}\% \text { of projects and } \\
\text { programs with } \\
\text { measured output } \\
\text { and/or outcome } \\
\text { indicators in the } \\
\text { M\&A database }\end{array}$ & 0 & $\begin{array}{l}100 \% \\
\text { With output } \\
\text { indicators }\end{array}$ & & $\begin{array}{l}\text { Information } \\
\text { lacking }\end{array}$ & \\
\hline \multicolumn{10}{|c|}{ Statistical system: } \\
\hline \multirow{4}{*}{$\begin{array}{l}\text { Create a new } \\
\text { improved } \\
\text { national statistics } \\
\text { system }\end{array}$} & \multirow{2}{*}{$\begin{array}{l}\text { Publication in } \\
\text { the Official } \\
\text { Bulletin of } \\
\text { enabling } \\
\text { decrees for the } \\
\text { Statistics Law } \\
\text { Law No. } \\
35 / V I I / 2009 \\
\text { BO No. } 9 \text { of } \\
\text { March } 2\end{array}$} & \multirow{2}{*}{$\begin{array}{l}\text { New INE } \\
\text { organizational } \\
\text { structure prepared }\end{array}$} & \multirow{2}{*}{$\begin{array}{l}\text { Evaluate } \\
\text { implementation of } \\
\text { the 2007-2010 } \\
\text { plan of action } \\
\text { (Statistics Agenda) }\end{array}$} & $\begin{array}{l}\text { Statistics Law } \\
\text { passed }\end{array}$ & $\begin{array}{l}\text { Statistics } \\
\text { Law passed }\end{array}$ & N/A & $\mathrm{N} / \mathrm{A}$ & N/A & MFAP/INE \\
\hline & & & & $\begin{array}{l}\text { New statute for } \\
\text { INE }\end{array}$ & & & $100 \%$ & & INE \\
\hline & \multirow{2}{*}{$\begin{array}{l}\text { QUIBB } 2007 \\
\text { data through } \\
\text { STATLINE } \\
\text { (national } \\
\text { statistical data } \\
\text { website) } \\
\text { (Completed) }\end{array}$} & $\begin{array}{l}\text { Conclusion of the } \\
\text { platform linking INE } \\
\text { to the national M\&A } \\
\text { system }\end{array}$ & \multirow{2}{*}{$\begin{array}{l}\text { Conclusion of the } \\
\text { public sector } \\
\text { survey, population } \\
\text { census, statistics } \\
\text { on employment } \\
\text { and tourism }\end{array}$} & $\begin{array}{l}\% \text { of QUIBB data } \\
\text { in Statline }\end{array}$ & $40 \%$ & $100 \%$ & Completed & INE site & INE/NOSI \\
\hline & & $\begin{array}{l}\text { Conclusion of survey } \\
\text { on tourist spending }\end{array}$ & & $\begin{array}{l}\text { Survey data in } \\
\text { Statline }\end{array}$ & N/A & $100 \%$ & Completed & INE site & $\begin{array}{l}\mathrm{INE} / \text { sector } \\
\text { ministries }\end{array}$ \\
\hline
\end{tabular}




\begin{tabular}{|c|c|c|c|c|c|c|c|c|c|}
\hline & & $\begin{array}{l}\text { Compilation of } \\
\text { administrative and } \\
\text { private sector data on } \\
\text { tourism and } \\
\text { employment }\end{array}$ & & & & & & & \\
\hline \multicolumn{10}{|c|}{ Modernization of the State: } \\
\hline \multirow{2}{*}{$\begin{array}{l}\text { Rationalization } \\
\text { of government } \\
\text { structures to } \\
\text { make public } \\
\text { administration } \\
\text { more cost } \\
\text { effective }\end{array}$} & \multirow{2}{*}{$\begin{array}{l}\text { Five ministries } \\
\text { restructured as } \\
\text { reflected in the } \\
2009 \text { State } \\
\text { budget } \\
\text { (Completed) }\end{array}$} & \multirow{2}{*}{$\begin{array}{l}\text { Continued } \\
\text { implementation of } \\
\text { restructuring } \\
\text { recommendations }\end{array}$} & \multirow{2}{*}{$\begin{array}{l}\text { Continued } \\
\text { implementation of } \\
\text { restructuring } \\
\text { recommendations }\end{array}$} & $\begin{array}{l}\text { Research functions } \\
\text { in three institutions } \\
\text { transferred to the } \\
\text { University of Cape } \\
\text { Verde }\end{array}$ & 0 & 1 & 3 & $\begin{array}{l}\text { BO No. } 36 \\
\text { series I } \\
9 / 10 / 08\end{array}$ & \multirow{2}{*}{ UCRE } \\
\hline & & & & $\begin{array}{l}\text { DGPOG posts } \\
\text { effectively staffed }\end{array}$ & & & 10 & 25 & \\
\hline \multicolumn{10}{|c|}{ Decentralization: } \\
\hline $\begin{array}{l}\text { Municipal } \\
\text { management } \\
\text { capacity } \\
\text { strengthening }\end{array}$ & $\begin{array}{l}\text { At least } 14 \\
\text { municipalities } \\
\text { connected to } \\
\text { the SIM and } \\
\text { training their } \\
\text { staff (17 } \\
\text { municipalities } \\
\text { have SIM) }\end{array}$ & $\begin{array}{l}17 \text { municipalities } \\
\text { connected to the } \\
\text { municipal information } \\
\text { system (SIM) }\end{array}$ & $\begin{array}{l}22 \text { municipalities } \\
\text { connected to the } \\
\text { SIM }\end{array}$ & $\begin{array}{l}\text { Number of } \\
\text { municipalities that } \\
\text { prepare accounts } \\
\text { on time }\end{array}$ & 3 & 9 & 14 & $\begin{array}{l}\text { Final } \\
\text { MDHOT } \\
\text { report } 2009\end{array}$ & NOSI-DGAL \\
\hline \multicolumn{10}{|c|}{ Reform of public administration: } \\
\hline $\begin{array}{l}\text { Promote merit- } \\
\text { based public } \\
\text { administration } \\
\text { and increase } \\
\text { possibilities for } \\
\text { internal and } \\
\text { external } \\
\text { mobility. }\end{array}$ & $\begin{array}{l}\text { Approval of the } \\
\text { Decree on } \\
\text { Mobility by the } \\
\text { Council of } \\
\text { Ministers } \\
\text { (Completed) }\end{array}$ & $\begin{array}{l}\text { Approval of the new } \\
\text { posts, careers, and } \\
\text { salaries plan (PCCS) } \\
\text { by the Council of } \\
\text { Ministers }\end{array}$ & $\begin{array}{l}\text { Implementation of } \\
\text { the new posts, } \\
\text { careers, and } \\
\text { salaries plan } \\
\text { (PCCS) }\end{array}$ & $\begin{array}{l}\text { Staff turnover in } \\
\text { leadership posts } \\
\text { (not mobility) (\%) }\end{array}$ & $\mathrm{n} / \mathrm{a}$ & $\mathrm{n} / \mathrm{a}$ & -5 & -10 & UCRE \\
\hline
\end{tabular}




\begin{tabular}{|c|c|c|c|c|c|c|}
\hline Security: & & & & & & \\
\hline \multirow{5}{*}{$\begin{array}{l}\text { Improved } \\
\text { security quality } \\
\text { in Cape Verdean } \\
\text { Territory }\end{array}$} & $\begin{array}{l}\text { General progress } \\
\text { of the sector } \\
\text { security matrix }\end{array}$ & & $\begin{array}{c}60 \% \text { of } \\
\text { indicators } \\
\text { achieved }\end{array}$ & $\begin{array}{c}60 \% \text { of } \\
\text { indicators } \\
\text { achieved }\end{array}$ & $\begin{array}{c}60 \% \text { of } \\
\text { indicators } \\
\text { achieved }\end{array}$ & \\
\hline & $\begin{array}{l}\% \text { of cases } \\
\text { investigated by the } \\
\text { judicial police and } \\
\text { sent to court with } \\
\text { charges brought }\end{array}$ & 54.6 & 55.0 & 65.68 & $\begin{array}{l}\text { PJ report } \\
\text { Jan-Dec } \\
2009\end{array}$ & \\
\hline & \multirow{3}{*}{$\begin{array}{l}\text { Creation and } \\
\text { implementation of } \\
\text { the Financial } \\
\text { Investigation Unit } \\
\text { (UIF) }\end{array}$} & $\begin{array}{l}\text { Creation of } \\
\text { the UIF }\end{array}$ & $\begin{array}{c}\text { Appointme } \\
\text { nt of senior } \\
\text { staff of the } \\
\text { UIF }\end{array}$ & Completed & & \multirow{3}{*}{ UIH } \\
\hline & & & $\begin{array}{c}\text { Work } \\
\text { program }\end{array}$ & Completed & & \\
\hline & & & $\begin{array}{c}\text { Manual on } \\
\text { distribution } \\
\text { of work and } \\
\text { internal } \\
\text { procedures }\end{array}$ & $\begin{array}{l}\text { An internal } \\
\text { regulation } \\
\text { for the UIF } \\
\text { has been } \\
\text { prepared }\end{array}$ & & \\
\hline
\end{tabular}




\begin{tabular}{|c|c|c|c|c|c|c|c|c|c|c|}
\hline \multirow{2}{*}{$\begin{array}{l}\text { Medium-term } \\
\text { objectives }\end{array}$} & \multirow[b]{2}{*}{ No. } & \multicolumn{3}{|c|}{ Policy measures and actions } & \multirow[b]{2}{*}{ Indicators } & \multirow{2}{*}{$\begin{array}{l}\text { Base } \\
2008\end{array}$} & \multicolumn{3}{|c|}{ Reference points } & \multirow{2}{*}{$\begin{array}{c}\text { Monitoring } \\
\text { (entity } \\
\text { responsible) }\end{array}$} \\
\hline & & 2009 & 2010 & 2011 & & & 2009 & $\begin{array}{l}2009 \\
\text { result }\end{array}$ & $\begin{array}{l}\text { Verificati } \\
\text { on doc. }\end{array}$ & \\
\hline \multicolumn{11}{|c|}{ Pillar 2- Human Capital } \\
\hline \multicolumn{11}{|c|}{ Primary education: } \\
\hline \multirow{3}{*}{ Improve quality } & & $\begin{array}{l}\text { Reduce the } \\
\text { number of } \\
\text { untrained } \\
\text { teachers }\end{array}$ & & & \multirow{3}{*}{$\begin{array}{l}\% \text { of primary } \\
\text { school teachers } \\
\text { with pedagogic } \\
\text { training }\end{array}$} & \multirow{3}{*}{82} & \multirow{3}{*}{84} & \multirow{3}{*}{86.5} & \multirow{3}{*}{$\begin{array}{l}\text { Annual } \\
\text { report }\end{array}$} & \multirow{3}{*}{$\begin{array}{l}\text { GEP / Ministry } \\
\text { of Education }\end{array}$} \\
\hline & & $\begin{array}{l}\text { Strengthening } \\
\text { of pedagogic } \\
\text { monitoring }\end{array}$ & & & & & & & & \\
\hline & & $\begin{array}{l}\text { Review } \\
\text { program for } \\
\text { each cycle }\end{array}$ & & & & & & & & \\
\hline \multicolumn{11}{|c|}{ Secondary education: } \\
\hline \multirow{3}{*}{$\begin{array}{l}\text { Improve } \\
\text { efficiency }\end{array}$} & & $\begin{array}{l}\text { Reduce the } \\
\text { number of } \\
\text { untrained } \\
\text { teachers }\end{array}$ & & & \multirow{3}{*}{$\begin{array}{l}\text { Secondary school } \\
\text { dropout rate (\%) }\end{array}$} & \multirow{3}{*}{8.2} & \multirow{3}{*}{8.1} & \multirow{3}{*}{8.0} & \multirow{3}{*}{$\begin{array}{l}\text { Annual } \\
\text { report }\end{array}$} & \multirow{3}{*}{$\begin{array}{l}\text { GEP / Ministry } \\
\text { of Education }\end{array}$} \\
\hline & & $\begin{array}{l}\text { Strengthening } \\
\text { of pedagogic } \\
\text { monitoring }\end{array}$ & & & & & & & & \\
\hline & & $\begin{array}{l}\text { Review } \\
\text { program for } \\
\text { each cycle }\end{array}$ & & & & & & & & \\
\hline \multicolumn{11}{|c|}{ Technical education: } \\
\hline Improve access & & $\begin{array}{l}\text { Coordinate the } \\
\text { program with } \\
\text { vocational } \\
\text { training }\end{array}$ & & & $\begin{array}{l}\% \text { of third cycle } \\
\text { secondary school } \\
\text { students going on } \\
\text { to technical } \\
\text { education }\end{array}$ & 13.8 & 13.9 & 14.3 & $\begin{array}{l}\text { Annual } \\
\text { report }\end{array}$ & $\begin{array}{l}\text { GEP / Ministry } \\
\text { of Education }\end{array}$ \\
\hline
\end{tabular}




\begin{tabular}{|c|c|c|c|c|c|c|c|c|}
\hline Vocational ed & and training ( $E$ & sino e formação profi & & & & & & \\
\hline \multirow{3}{*}{$\begin{array}{l}\text { Upgrade labor } \\
\text { skills to satisfy } \\
\text { market demand }\end{array}$} & $\begin{array}{l}\text { Undertake } \\
\text { studies to } \\
\text { estimate future } \\
\text { demand for } \\
\text { labor and EFP } \\
\text { training needs } \\
\text { in various } \\
\text { sectors }\end{array}$ & & $\begin{array}{l}\text { Number of sector } \\
\text { studies completed }\end{array}$ & 0 & 2 & 3 & $\begin{array}{l}\text { 1- } \\
\text { Employme } \\
\text { nt market } \\
\text { study } \\
\text { 2- } \\
\text { Vocational } \\
\text { training } \\
\text { charter } \\
\text { 3-Vocatio } \\
\text { nal training } \\
\text { glossary }\end{array}$ & \multirow{3}{*}{$\begin{array}{l}\text { Ministries of } \\
\text { Employment and } \\
\text { Vocational } \\
\text { Training; } \\
\text { Education; and } \\
\text { Finance }\end{array}$} \\
\hline & $\begin{array}{l}\text { Reactivate } \\
\text { platforms that } \\
\text { satisfy supply } \\
\text { and demand for } \\
\text { EFP on each } \\
\text { island }\end{array}$ & $\begin{array}{l}\text { Proposed } \\
\text { restructuring of the } \\
\text { IEFP approved } \\
\text { in the Council of } \\
\text { Ministers }\end{array}$ & $\begin{array}{l}\text { Implementation } \\
\text { rate (\%) of annual } \\
\text { plans of } \\
\text { Employment } \\
\text { Center in } \\
\text { Mindelo and Praia }\end{array}$ & $\mathrm{n} / \mathrm{a}$ & $>60$ & 90 & $\begin{array}{l}\text { Report on } \\
\text { IEFP and } \\
\text { Employme } \\
\text { nt center } \\
\text { activities }\end{array}$ & \\
\hline & $\begin{array}{l}\text { Ministerial } \\
\text { decision to } \\
\text { reactivate and } \\
\text { improve the } \\
\text { Training } \\
\text { Support Fund } \\
\text { (FAF) } \\
\text { (Completed) }\end{array}$ & $\begin{array}{l}\text { Contracts with } \\
\text { suppliers signed for } \\
\text { up } € 600,000 \text { to be } \\
\text { financed from the } \\
\text { Vocational Training } \\
\text { Financing Fund }\end{array}$ & $\begin{array}{l}\% \text { of FAF funds } \\
\text { used for EFP }\end{array}$ & 0 & $>20$ & 100.0 & $\begin{array}{l}\text { Protocols } \\
\text { signed } \\
\text { Minutes of } \\
\text { CA FEFP; } \\
\text { Financial } \\
\text { execution } \\
\text { report }\end{array}$ & \\
\hline
\end{tabular}




\begin{tabular}{|c|c|c|c|c|c|c|c|c|c|c|}
\hline \multirow{2}{*}{$\begin{array}{l}\text { Medium-term } \\
\text { objectives }\end{array}$} & \multirow[b]{2}{*}{ No. } & \multicolumn{3}{|c|}{ Policy measures and actions } & \multirow[b]{2}{*}{ Indicators } & \multirow{2}{*}{$\begin{array}{l}\text { Base } \\
2008\end{array}$} & \multicolumn{3}{|c|}{ Reference points } & \multirow{2}{*}{$\begin{array}{l}\text { Monitoring } \\
\text { (entity } \\
\text { responsible) }\end{array}$} \\
\hline & & 2009 & 2010 & 2011 & & & 2009 & $\begin{array}{l}2009 \\
\text { result }\end{array}$ & $\begin{array}{l}\text { Verificati } \\
\text { on doc. }\end{array}$ & \\
\hline \multicolumn{11}{|c|}{ Pillar 3-Competitiveness } \\
\hline \multicolumn{11}{|c|}{ International trade } \\
\hline $\begin{array}{l}\text { Greater } \\
\text { involvement by } \\
\text { CV in } \\
\text { international } \\
\text { trade }\end{array}$ & & $\begin{array}{l}\text { New Customs } \\
\text { Code in } \\
\text { compliance } \\
\text { with WTO } \\
\text { principles } \\
\text { approved in the } \\
\text { Council of } \\
\text { Ministers }\end{array}$ & $\begin{array}{l}\text { Investment Code } \\
\text { reviewed in } \\
\text { accordance with } \\
\text { principles defined by } \\
\text { the WTO in draft }\end{array}$ & $\begin{array}{l}\text { New draft law on } \\
\text { intellectual } \\
\text { property }\end{array}$ & $\begin{array}{l}\text { Openness to trade, } \\
\text { i.e. (imports }+ \\
\text { exports of goods } \\
\text { and services, credit } \\
+ \text { debit)/as a } \\
\text { percentage of GDP }\end{array}$ & 107 & 107 & $\begin{array}{l}\text { Information } \\
\text { lacking }\end{array}$ & & $\begin{array}{l}\text { Ministry of } \\
\text { Economy, Growth } \\
\text { and } \\
\text { Competitiveness } \\
\text { (MECC) }\end{array}$ \\
\hline \multicolumn{11}{|l|}{ Tourism: } \\
\hline \multirow{3}{*}{$\begin{array}{l}\text { Wide ranging } \\
\text { and sustainable } \\
\text { strategy with } \\
\text { greater local } \\
\text { content }\end{array}$} & & \multirow{3}{*}{$\begin{array}{l}\text { Master plan } \\
\text { approved by } \\
\text { Council of } \\
\text { Ministers } \\
\text { (Completed) }\end{array}$} & $\begin{array}{l}\text { Starting point for all } \\
\text { indicators of local } \\
\text { content }\end{array}$ & \multirow{3}{*}{$\begin{array}{l}\text { New revised } \\
\text { legislation } \\
\text { approved for the } \\
\text { tourism sector }\end{array}$} & \multirow{3}{*}{$\begin{array}{l}\text { Number of } \\
\text { EHTCV training } \\
\text { events }\end{array}$} & \multirow{3}{*}{0} & \multirow{3}{*}{$\begin{array}{c}5 \\
\text { School still } \\
\text { being built }\end{array}$} & \multirow{3}{*}{$\begin{array}{l}\text { Strategic } \\
\text { plan } \\
\text { approved } \\
\text { by Council } \\
\text { of } \\
\text { Ministers in } \\
\text { December } \\
2009\end{array}$} & & \multirow{3}{*}{ MECC } \\
\hline & & & $\begin{array}{l}\text { Cape Verdean School } \\
\text { of Hotel Management } \\
\text { and Tourism (EHTCV) } \\
\text { operating }\end{array}$ & & & & & & & \\
\hline & & & $\begin{array}{l}\text { Tourism satellite } \\
\text { accounts implemented }\end{array}$ & & & & & & & \\
\hline \multicolumn{11}{|l|}{ Financial sector: } \\
\hline \multirow{2}{*}{$\begin{array}{l}\text { Strengthen } \\
\text { stability }\end{array}$} & & $\begin{array}{l}2007 \\
\text { Microfinance } \\
\text { Law revised to } \\
\text { clarify } \\
\text { restrictions on } \\
\text { accepting } \\
\text { deposits } \\
\text { Not revised }\end{array}$ & $\begin{array}{l}\text { IFI legal framework } \\
\text { revised to align } \\
\text { regulatory regime with } \\
\text { onshore system }\end{array}$ & \multirow{2}{*}{$\begin{array}{l}\text { IFRS accounting } \\
\text { standards applied } \\
\text { to banks and } \\
\text { insurance } \\
\text { companies }\end{array}$} & \multirow{2}{*}{$\begin{array}{l}\text { Asset-weighted } \\
\text { average capital } \\
\text { adequacy ratio } \\
\text { (Basel 1) of whole } \\
\text { system in \% }\end{array}$} & \multirow{2}{*}{$\begin{array}{l}9.9 \\
\text { (includes } \\
\text { onshore } \\
\text { banks only) }\end{array}$} & \multirow[b]{2}{*}{$\geq 10$} & \multirow[b]{2}{*}{$\begin{array}{l}\text { Solvency of } \\
\text { the banking } \\
\text { system } \\
10 \%\end{array}$} & \multirow{2}{*}{$\begin{array}{l}\text { BO No. } 7 \\
\text { of } 16 / 02 / 09 \\
\text { and BO No. } \\
41 \text { of } \\
2 / 11 / 09 \\
\text { BCV report } \\
\text { and account } \\
\text { on the BCV } \\
\text { site }\end{array}$} & \multirow{2}{*}{$\begin{array}{l}\text { Banco de Cabo } \\
\text { Verde (central } \\
\text { bank) }\end{array}$} \\
\hline & & $\begin{array}{l}\text { Closure of } \\
\text { offshore } \\
\text { banks that do } \\
\text { not comply } \\
\text { with } \\
\text { legislation ( } 2 \\
\text { offshore banks } \\
\text { closed) }\end{array}$ & $\begin{array}{l}\text { Legal framework of } \\
\text { banking supervision } \\
\text { revised to give greater } \\
\text { authority to the BCV }\end{array}$ & & & & & & & \\
\hline
\end{tabular}




\begin{tabular}{|c|c|c|c|c|c|c|c|c|c|}
\hline \multicolumn{10}{|l|}{ Taxation: } \\
\hline \multirow{2}{*}{$\begin{array}{l}\text { Alignment of } \\
\text { reduction in } \\
\text { taxes and tax } \\
\text { incentives to } \\
\text { improve the } \\
\text { investment } \\
\text { climate }\end{array}$} & \multirow{2}{*}{$\begin{array}{l}\text { Generalized } \\
\text { reduction in } \\
\text { business taxes }\end{array}$} & \multirow{2}{*}{$\begin{array}{l}\text { Draft law on tax } \\
\text { incentives approved by } \\
\text { the Council of } \\
\text { Ministers }\end{array}$} & \multirow{2}{*}{$\begin{array}{l}\text { Law passed by } \\
\text { Parliament }\end{array}$} & $\begin{array}{l}\text { Percentage of } \\
\text { taxes }\end{array}$ & \multirow[b]{2}{*}{30} & \multirow[b]{2}{*}{25} & \multirow[b]{2}{*}{25} & \multirow{2}{*}{$\begin{array}{l}\text { BO No. } 48 \\
\text { 29/Dec/08 }\end{array}$} & \\
\hline & & & & Investments & & & & & \\
\hline \multicolumn{10}{|c|}{ Business climate: } \\
\hline $\begin{array}{l}\text { Improved } \\
\text { government } \\
\text { services }\end{array}$ & $\begin{array}{l}\text { Citizens Advice } \\
\text { Bureau (Casa do } \\
\text { Cidadão) } \\
\text { operational with } \mathrm{x} \\
\text { services }\end{array}$ & $\begin{array}{l}\text { Proposed bankruptcy } \\
\text { law prepared }\end{array}$ & & $\begin{array}{l}\text { No. of firms } \\
\text { created through the } \\
\text { Citizens Advice } \\
\text { Bureau per year }\end{array}$ & 600 & 630 & 780 & $\begin{array}{c}\text { www.porto } \\
\text { ndinosilha.c } \\
\text { v }\end{array}$ & $\begin{array}{c}\text { MREDN } \\
\text { Citizens Advice } \\
\text { Bureau }\end{array}$ \\
\hline
\end{tabular}




\begin{tabular}{|c|c|c|c|c|c|c|c|c|c|}
\hline \multicolumn{10}{|c|}{ Environmental management: } \\
\hline $\begin{array}{l}\text { Satisfactory } \\
\text { implementation } \\
\text { of the } \\
\text { government's } \\
\text { environment } \\
\text { policy (PANA } \\
\text { II) }\end{array}$ & $\begin{array}{l}\text { Implementation } \\
\text { of PANA II }\end{array}$ & $\begin{array}{l}\text { Implementation of } \\
\text { PANA II }\end{array}$ & $\begin{array}{l}\text { Implementation of } \\
\text { PANA II }\end{array}$ & $\begin{array}{l}\text { Evaluation of the } \\
\text { report on annual } \\
\text { implementation of } \\
\text { PANA II by the } \\
\text { CNA }\end{array}$ & $\begin{array}{l}\text { Positive } \\
\text { evaluation } \\
\text { by the CNA }\end{array}$ & $\begin{array}{l}\text { Positive } \\
\text { evaluation } \\
\text { by the CNA }\end{array}$ & $\begin{array}{l}\text { Positive } \\
\text { evaluation } \\
\text { by the CNA }\end{array}$ & & $\begin{array}{l}\text { Annual PANA } \\
\text { II progress report } \\
\text { and minutes of } \\
\text { CNA meetings }\end{array}$ \\
\hline $\begin{array}{l}\text { Improvement of } \\
\text { sector } \\
\text { governance }\end{array}$ & $\begin{array}{l}\text { See specific } \\
\text { sector matrix }\end{array}$ & $\begin{array}{l}\text { See specific sector } \\
\text { matrix }\end{array}$ & $\begin{array}{l}\text { See specific sector } \\
\text { matrix }\end{array}$ & $\begin{array}{l}\text { Average of good } \\
\text { governance criteria } \\
\text { (c.f. Sector matrix) }\end{array}$ & $\begin{array}{l}\text { Average of } \\
\text { at least } 60 \%\end{array}$ & $\begin{array}{l}\text { Average of } \\
\text { at least } \\
60 \%\end{array}$ & $\begin{array}{l}\text { (Achieved } \\
68.75 \% \text { ) }\end{array}$ & & \\
\hline $\begin{array}{l}\text { Improve } \\
\text { environmental } \\
\text { conditions }\end{array}$ & $\begin{array}{l}\text { See specific } \\
\text { sector matrix }\end{array}$ & $\begin{array}{l}\text { See specific sector } \\
\text { matrix }\end{array}$ & $\begin{array}{l}\text { See specific sector } \\
\text { matrix }\end{array}$ & $\begin{array}{l}\text { Average of } \\
\text { environmental } \\
\text { management } \\
\text { criteria (c.f. Sector } \\
\text { budget support } \\
\text { matrix) }\end{array}$ & $\begin{array}{l}\text { Average of } \\
\text { at least } 60 \%\end{array}$ & $\begin{array}{l}\text { Average of } \\
\text { at least } \\
60 \%\end{array}$ & $\begin{array}{l}\text { (Achieved } \\
66.5 \%)\end{array}$ & & $\begin{array}{l}\text { budget support } \\
\text { partners during } \\
\text { joint missions }\end{array}$ \\
\hline \multicolumn{10}{|l|}{ Energy: } \\
\hline \multirow{2}{*}{$\begin{array}{l}\text { Restore financial } \\
\text { viability of the } \\
\text { electricity sector }\end{array}$} & \multirow{4}{*}{$\begin{array}{l}\text { Formulate the } \\
\text { medium-term } \\
\text { sector development } \\
\text { strategy, } \\
\text { including } \\
\text { institutional } \\
\text { evolution of } \\
\text { Electra } \\
\text { (achieved } 66.5 \%)\end{array}$} & \multirow[b]{2}{*}{$\begin{array}{l}\text { Investments to reduce } \\
\text { Electra production } \\
\text { costs } \\
\end{array}$} & & $\begin{array}{l}\text { Electra debt } \\
\text { service coverage } \\
\text { ratio }\end{array}$ & 0.3 & 0.75 & 0.7 & $\begin{array}{l}\text { Awaiting } \\
\text { official } \\
\text { document }\end{array}$ & \multirow{4}{*}{ ARE / MECC } \\
\hline & & & & $\begin{array}{l}\text { Technical and } \\
\text { nontechnical losses } \\
\text { as \% of MGW } \\
\text { production }\end{array}$ & 30 & 28 & 26.13 & $\begin{array}{l}\text { Electra } \\
\text { Planning } \\
\text { Department }\end{array}$ & \\
\hline \multirow{2}{*}{$\begin{array}{l}\text { Increase } \\
\text { production } \\
\text { capacity, } \\
\text { including } \\
\text { renewable } \\
\text { energy }\end{array}$} & & \multirow{2}{*}{$\begin{array}{l}\text { Investments in } \\
\text { production capacity of } \\
(\ldots) ?\end{array}$} & & $\begin{array}{l}\text { Production } \\
\text { capacity in MW }\end{array}$ & 73.9 & 77.6 & 98 & $\begin{array}{l}\text { Information } \\
\text { from } \\
\text { DGEnergia }\end{array}$ & \\
\hline & & & & $\begin{array}{l}\% \text { of renewable } \\
\text { energy }\end{array}$ & 3 & 3 & 3 & $\begin{array}{l}\text { Awaiting } \\
\text { information } \\
\text { from } \\
\text { DGEnergia } \\
\end{array}$ & \\
\hline
\end{tabular}




\begin{tabular}{|c|c|c|c|c|c|c|c|c|c|c|}
\hline \multirow{2}{*}{$\begin{array}{l}\text { Medium-term } \\
\text { objectives }\end{array}$} & \multirow[b]{2}{*}{ No. } & \multicolumn{3}{|c|}{ Policy measures and actions } & \multirow[b]{2}{*}{ Indicators } & \multirow{2}{*}{$\begin{array}{l}\text { Base } \\
2008\end{array}$} & \multicolumn{3}{|c|}{ Reference points } & \multirow{2}{*}{$\begin{array}{l}\text { Monitoring } \\
\text { (entity } \\
\text { responsible) }\end{array}$} \\
\hline & & 2009 & 2010 & 2011 & & & 2009 & $\begin{array}{l}2009 \\
\text { result }\end{array}$ & $\begin{array}{l}\text { Veririfcat } \\
\text { ion doc. }\end{array}$ & \\
\hline \multicolumn{11}{|c|}{ Pillar 5 social cohesion } \\
\hline \multicolumn{11}{|c|}{ Target social actions: } \\
\hline \multirow{3}{*}{ Pilot program } & & $\begin{array}{l}\text { Qualitative } \\
\text { survey and plan } \\
\text { of action }\end{array}$ & Pilot program & $\begin{array}{l}\text { Evaluation of the } \\
\text { performance of } \\
\text { targeting systems }\end{array}$ & \multirow{3}{*}{$\begin{array}{l}\text { Number of people } \\
\text { receiving social } \\
\text { pensions }\end{array}$} & \multirow{3}{*}{22,500} & \multirow{3}{*}{22,900} & \multirow{3}{*}{22,946} & \multirow{3}{*}{$\begin{array}{l}\text { Activities } \\
\text { report } 2009\end{array}$} & \multirow{3}{*}{ MTS } \\
\hline & & $\begin{array}{l}\text { Updating of the } \\
\text { poverty map }\end{array}$ & $\begin{array}{l}\text { Development of } \\
\text { similar methods: } \\
\text { (Training and surveys) }\end{array}$ & $\begin{array}{l}\text { Map updated with } \\
\text { the } 2010 \text { Census }\end{array}$ & & & & & & \\
\hline & & & $\begin{array}{l}\text { Map updated with } \\
\text { QUIBB } 2007\end{array}$ & & & & & & & \\
\hline \multicolumn{11}{|c|}{ Support for priority sectors: } \\
\hline Education & & $\begin{array}{l}\text { Implement } \\
\text { PRGS II } \\
\text { priorities } \\
2009 \text { budget }\end{array}$ & $\begin{array}{l}\text { Implement } \\
\text { PRGS II priorities in } \\
2010 \text { budget }\end{array}$ & $\begin{array}{l}\text { Implement PRGS } \\
\text { II priorities } \\
\text { in } 2011 \text { budget }\end{array}$ & $\begin{array}{l}\text { Education budget } \\
\text { execution rate - } \\
\text { investment with } \\
\text { own funds }\end{array}$ & $78 \%$ & $>80 \%$ & $82 \%$ & SIGOF & $\begin{array}{l}\text { General Planning } \\
\text { Department } \\
(\mathrm{MF})\end{array}$ \\
\hline Health & & $\begin{array}{l}\text { Implement } \\
\text { PRGS II } \\
\text { priorities } \\
2009 \text { budget }\end{array}$ & $\begin{array}{l}\text { Implement } \\
\text { PRGS II priorities in } \\
2010 \text { budget }\end{array}$ & $\begin{array}{l}\text { Implement PRGS } \\
\text { II priorities } \\
\text { in } 2011 \text { budget }\end{array}$ & $\begin{array}{l}\text { Health budget } \\
\text { execution rate - } \\
\text { investment with } \\
\text { own funds }\end{array}$ & $70.0 \%$ & $>75 \%$ & $98 \%$ & SIGOF & DGP \\
\hline \multicolumn{11}{|c|}{ Protect vulnerable people: } \\
\hline Provide housing & & $\begin{array}{l}\text { Creation of the } \\
\text { Social Housing } \\
\text { Promotion } \\
\text { Fund }\end{array}$ & $\begin{array}{l}\text { Provide financial } \\
\text { resources to the fund }\end{array}$ & $\begin{array}{l}\text { Provide financial } \\
\text { resources to the } \\
\text { fund }\end{array}$ & $\begin{array}{l}\text { Number of } \\
\text { vulnerable persons } \\
\text { accommodated or } \\
\text { benefiting from } \\
\text { rehabilitation of } \\
\text { their homes }\end{array}$ & 628 & 700 & & $\begin{array}{l}\text { Report data } \\
\text { need to be } \\
\text { reviewed }\end{array}$ & $\begin{array}{l}\text { Ministry of } \\
\text { Housing, IFH } \\
\text { Municipalities } \\
\text { SHP fund }\end{array}$ \\
\hline $\begin{array}{l}\text { Provide access to } \\
\text { basic legal advice } \\
\text { on the most } \\
\text { urgent legal } \\
\text { issues }\end{array}$ & & $\begin{array}{l}\text { Creation and } \\
\text { rehabilitation } \\
\text { of broad- } \\
\text { coverage legal } \\
\text { centers }\end{array}$ & $\begin{array}{l}\text { Measure to be decided } \\
\text { on to guarantee the } \\
\text { sustainability of legal } \\
\text { centers }\end{array}$ & & $\begin{array}{l}\text { Number of legal } \\
\text { centers operating }\end{array}$ & 7 & 11 & 11 & $\begin{array}{l}\text { Report by } \\
\text { Legal } \\
\text { Advice } \\
\text { Bureau } \\
\text { (Casa } \\
\text { Direito) }\end{array}$ & $\begin{array}{l}\text { Ministry of } \\
\text { Justice / PIU }\end{array}$ \\
\hline
\end{tabular}




\begin{tabular}{|c|c|c|c|c|c|c|c|c|c|c|}
\hline \multirow{2}{*}{$\begin{array}{l}\text { Medium-term } \\
\text { objectives }\end{array}$} & \multirow[b]{2}{*}{ No. } & \multicolumn{3}{|c|}{ Policy measures and actions } & \multirow[b]{2}{*}{ Indicators } & \multirow{2}{*}{$\begin{array}{l}\text { Base } \\
2008\end{array}$} & \multicolumn{3}{|c|}{ Reference points } & \multirow{2}{*}{$\begin{array}{l}\text { Monitoring } \\
\text { (entity } \\
\text { responsible) }\end{array}$} \\
\hline & & 2009 & 2010 & 2011 & & & 2009 & $\begin{array}{l}2009 \\
\text { result }\end{array}$ & $\begin{array}{l}\text { Veririfcat } \\
\text { ion doc. }\end{array}$ & \\
\hline & & & $\begin{array}{l}\text { Data collection system } \\
\text { created }\end{array}$ & & $\begin{array}{l}\text { Number of } \\
\text { advisory services } \\
\text { per legal center }\end{array}$ & 150 & $>200$ & 276 & $\begin{array}{l}\text { Report by } \\
\text { Legal } \\
\text { Advice } \\
\text { Bureau } \\
\text { (Casa } \\
\text { Direito) }\end{array}$ & \\
\hline
\end{tabular}


ARE - Agência de Regulação Económica [Economic Regulation Agency]

ARAP - Agência Reguladora de Aquisições Públicas [Public Procurement Regulator]

CIAP- Comissão Independente para Aquisições Públicas [Independent Public Procurement Commission]

CNA - Conselho Nacional do Ambiente [National Environment Council]

ELECTRA- Companhia de Electricidade e Água [Electricity and water company]

MECC - Ministério da Economia Crescimento e Competitividade [Ministry of Economy, Growth, and Competitiveness]

NOSI- Núcleo Operacional da Sociedade de Informação [Information society operational unit]

PCCS - Plano de Cargos Carreiras e Salários [Posts, careers, and salaries plan]

RBM - Monitorização com Base nos Resultados [Results-based monitoring]

$\mathrm{SP}$ - Protecção Social [Social protection]

TdC - Tribunal de Contas [Auditor General's Office]

TSF - Fundo de Apoio à Formação [Training Support Fund]

TVET- Formação e Ensino Técnico e Profissional [Technical and vocational training and education]

UGA- Unidade de Gestão de Aquisições [Procurement Management Unit]

UCRE- Unidade de Coordenação para a Reforma do Estado [State Reform Coordination Unit] 